HID 48 (2021)

\title{
LA BIBLIOTECA DEL I MARQUÉS DEL CENETE (1468-1523) COMO PARADIGMA DEL COLECCIONISMO BIBLIOGRÁFICO RENACENTISTA ${ }^{1}$
}

\author{
THE LIBRARY OF THE $1^{\text {ST }}$ MARQUIS OF THE CENETE (1468-1523) AS \\ A PARADIGM OF RENAISSANCE BIBLIOGRAPHIC COLLECTING
}

\author{
ESTEFANIA FERRER DEL RÍO \\ Universitat de València \\ estefania.ferrer-rio@uv.es ORCID: https://orcid.org/0000-0001-5712-8521
}

RESUMEN: En el presente trabajo analizamos la colección bibliográfica de 653 libros de Rodrigo de Mendoza, I marqués del Cenete, a través del inventario de bienes post mortem que se realizó a partir del 27 de febrero de 1523, tras su óbito. A pesar de que la información que proporciona el notario no es muy detallada, vislumbra suficientes detalles como para conocer las lenguas en las que estaban compuestas las obras, los diferentes autores que podían formar parte de su biblioteca de manera recurrente, sus lecturas más frecuentes y, quizá, preferidas, así como el material de los volúmenes en cuestión y la relación de todos aquellos que adquirieron parcialmente su biblioteca en las almonedas acaecidas entre 1529 y 1535. ¿Podría una biblioteca tan numerosa y exquisita para la época haberse convertido en paradigma del coleccionismo bibliográfico del Renacimiento hispano? Cuestión a la que pretendemos dar respuesta en estas líneas.

PAlabRas ClaVE: I marqués del Cenete; colección bibliográfica; libros y lecturas; manuscritos y libros impresos; Renacimiento; ss. XV-XVI.

ABSTRACT: In the present work, we analyze the bibliographic collection of 653 books of Rodrigo de Mendoza, It Marquis of the Cenete, through the inventory of post-mortem goods that was carried out as of February $27^{\text {th }}, 1523$, after his death. Although the information provided by the notary is not very detailed, it

Recibido: 28-10-2020; Aceptado: 5-2-2021; Versión definitiva: 23-2-2021

1. Este artículo se inscribe en el proyecto de investigación $\mathrm{I}+\mathrm{D}$ : "Memoria, imagen y conflicto en el arte y la arquitectura del Renacimiento: la revuelta de las Germanías de Valencia" (HAR201788707-P), financiado por el Ministerio de Ciencia e Innovación/AEI/FEDER, UE. Abreviaturas utilizadas: $\mathrm{AHN}=$ Archivo Histórico Nacional, DCVB = Diccionari Català-Valencià-Balear.

Copyright: (C) Editorial Universidad de Sevilla. Este es un artículo de acceso abierto distribuido bajo los términos de la licencia de uso y distribución Creative Commons Reconocimiento-NoComercialSinObraDerivada 4.0 (CC BY-NC-ND 4.0) 
glimpses enough details to know the languages in which the works were composed, the different authors that could be part of his library on a recurring basis, their most frequent readings and, perhaps, preferred, as well as the material of the volumes in question and the list of all those who partially acquired their library in the auction that took place between 1529 and 1535 . Could a library so numerous and exquisite for the time have become a paradigm of the bibliographic collecting of the Hispanic Renaissance? Question to which we intend to answer in these lines.

KEYWORDS: $1^{\text {st }}$ Marquis of the Cenete; bibliographic collection; books and readings; manuscripts and printed books; Renaissance; $15^{\text {th }}-16^{\text {th }}$ centuries.

\section{El estudio de LA BibliotecA}

Rodrigo Díaz de Vivar y Mendoza, I marqués del Cenete y I conde del Cid, primogénito del Gran Cardenal de España, suscitó el interés de historiadores de la primera mitad del siglo XX, sobre todo, su faceta coleccionista, centrada en su biblioteca, que llegó a estudiar Francisco José Sánchez Cantón en 1942. En dicho estudio, el historiador del arte transcribió los libros que aparecían registrados en el inventario de bienes post mortem que se inició 4 días después del óbito del marqués, exactamente el 27 de febrero de 1523. Se trataba de un total de 633 registros bibliográficos, además de una breve biografía del protagonista y un sencillo estudio de los mencionados libros.

No cabe destacar ahora los pormenores biográficos de Rodrigo de Mendoza, que hizo de su hipotético parentesco con el Cid Campeador el estandarte de su linaje, así como de sus acciones e, incluso, polémicas decisiones, sobre todo porque recientes investigaciones han sacado a colación detalles de su vida hasta ahora desconocidos ${ }^{2}$. Asimismo, sí resaltaremos que fruto de dichos estudios sobre la figura de nuestro protagonista y de sus bienes muebles e inmuebles, se pudo comprobar a través del inventario original ${ }^{3}$ anteriormente mencionado que no se trataba de 633 obras, como defendía el destacado historiador del arte, sino de 653. ¿A qué se debe esta diferencia? Básicamente a dos circunstancias: la primera, que la interpretación del inventario pudo llevar a confusión en la época en la que lo transcribió debido a que el notario, Jaume Bonavida, no se detuvo en corroborar los títulos que leía (o le dictaban) de las portadas o primeros folios de los ejemplares de la biblioteca del mendocino, $\mathrm{y}$, en muchas ocasiones, seguramente por un deficiente conocimiento del latín, se confundieron títulos e incluso autores, y, en algunas ocasiones, un mismo título aparecía repetido, hecho que quizá se interpretó como una errata y no se contabilizó como obra registrada, a pesar de que pudiera tratarse de una misma obra en varios volúmenes (como así se ha podido comprobar); la segunda y última, porque, además de las confusiones que pudo

2. Véanse los recientes estudios de Ferrer del Río 2016a, pp. 245-258, 2016b, pp. 85-100, 2017, pp. 467-496, 2018, pp. 467-496, у 2020.

3. AHN, Nobleza, Osuna, Caja 1.906, Documento 1. 
conllevar lo ya comentado, aparecen en una parte distinta del inventario, entre obras de arte, más de una decena de libros -entre ellos, cuatro misales-, que no son citados tampoco en el estudio de 1942.

A partir de este pretexto, queremos dar a conocer el estudio pormenorizado y, ante todo, actualizado de una de las bibliotecas nobiliarias más exquisitas y cuantiosas del momento, solo superada posteriormente por su primogénita Mencía. Un caballero que hizo honor a su formación militar participando como capitán en las diferentes contiendas del momento y que, a su vez, atesoró una fastuosa colección libraria repleta de autores clásicos e incluso humanistas, por lo que ¿pudo haber sido un humanista? De ser cierta la teoría de Sánchez Cantón sobre la formación inicial de dicha biblioteca por el Gran Cardenal, ¿hasta qué punto tuvo Rodrigo de Mendoza una implicación en la adquisición de sus obras? ¿Podía, además, dicha colección bibliográfica haberse convertido en un referente para otros nobles coetáneos o incluso de humanistas que estaban bajo la protección del marqués?

En este sentido, y para llegar a dar respuesta a las hipótesis planteadas, nos centraremos en el análisis de las lenguas de los libros, en qué tipo de libro se trata, la descripción de la encuadernación a través de los detalles que nos transmite el documento notarial, las temáticas de dichas obras, sus autores $\mathrm{y}$, por último, estudiaremos a los compradores que adquirieron obras pertenecientes al marqués durante las almonedas celebradas entre 1529 y 1535 en Valencia ${ }^{4}$.

\subsection{Las lenguas}

Al observar las lenguas usadas en la elaboración de las obras, podemos afirmar, sin lugar a dudas, que el latín era el idioma que predominaba sobremanera en la colección bibliográfica del marqués del Cenete. Circunstancia que nos plantea un importante dilema: ¿todas aquellas entradas que registra el notario son verdaderamente latinas o quizá sea una mala interpretación que del título de la encuadernación se hizo o, incluso, del primer folio de la obra en cuestión? Aquellas obras en las que identifica el 'vulgar' o 'romanç' sin más, ¿se refieren a qué lengua romance concretamente? ¿Podría darse también la circunstancia de que el notario castellanizara o catalanizara algunos títulos latinos por su mala lectura y/o sus dificultades con el latín? No hay más que observar en cuántas ocasiones hemos habido de rectificar en la identificación de la biblioteca lo anotado erróneamente por el notario, bien por un mal entendimiento de la lengua o por desconocimiento de la misma.

Lo más llamativo al encarar el inventario de libros es la gran cantidad de obras, efectivamente, en latín. Si realmente no hubiese sido un hombre culto y formado,

4. Desafortunadamente, y ya que nos basamos en hipótesis, no hemos considerado fehaciente un análisis ni de los lugares de edición ni de los impresores y editores, puesto que sabemos en un número muy reducido aquellas obras que solo tuvieron una edición, del resto es difícil acotar datos, puesto que, como ya hemos comentado, los registros que llevó a cabo el notario, sobre todo de los libros, son muy escasos y con poco detallismo, por norma general, siendo, en la mayoría de casos, una mera transcripción del título de la obra en cuestión que iba encontrándose a medida que iban abriendo cajas. 
sino simplemente alguien entregado a otros menesteres circunstanciales a su personalidad, sería extraño hallar tan gran volumen de obras latinas (suponiendo que no entendiera la lengua como su abuelo). También podríamos pensar que, tal y como ya hemos indicado con anterioridad, dichos ejemplares hubieran sido transferidos al noble a raíz del fallecimiento del cardenal Mendoza. Pero estaríamos en un error por un sencillo motivo: como más adelante matizaremos, es cierto que hay bastantes obras editadas antes de 1495, es decir, antes de que Pedro González de Mendoza pereciera; pero también encontramos otras, muy numerosas, además, cuya fecha de edición es posterior al óbito del prelado, hecho que nos demuestra que el aristócrata compró y engrosó el volumen de la colección bibliográfica heredada posiblemente de su padre.

Todo ello nos da a entender que, independientemente de la panorámica culta que reflejaba la biblioteca de su persona e incluso de su exquisito olfato para los bienes objeto de atesorar en su colección, era alguien que conocía la lengua de Virgilio, que sabía leerla y que tenía gusto por adquirir obras mayoritariamente en latín. Sin embargo, ¿y si realmente tenía dificultades con la lengua y por ello requirió de manuales glosados para poder ser mejor entendidos? Esta cuestión la analizaremos a continuación.

Por lo que respecta a este apartado, hemos detectado hasta 541 registros en lengua latina ${ }^{5}$, de los cuales la mayoría hemos podido identificar y corroborar, pero, en otros casos, hemos seguido la escasa información proporcionada por el notario Jaume Bonavida. En aquellos registros que, afortunadamente, transcriben el título completo, no hemos hallado problema alguno en identificar la lengua -como mínimo, de la interpretación que realiza el notario-, pero en los ejemplos que solo nos transmiten el autor, hemos llegado a la conclusión de que, al estar declinados (generalmente en nominativo singular e, incluso, en genitivo singular también), no dejan de ser una transcripción literal de lo que el notario fue observando y leyendo de las obras según las extrajo de las cajas.

Aun así, hemos de remarcar algunos ejemplares que pueden tener una interpretación ambigua, como, por ejemplo: el registro $\mathrm{n}^{\mathrm{o}} 33-55$ hace referencia a un conjunto de libros de poesía tanto en latín como en italiano, pero detalla cuántos son de una lengua y cuántos de otra, por lo que hemos incluido dicho registro por duplicado en ambos idiomas; o la entrada $n^{\circ} 78$ está descrita por Bonavida en latín, pero Sánchez Cantón la identifica como una edición en catalán.

En segundo lugar, destacan las obras en lengua castellana $\left(37\right.$ en total $\left.^{6}\right)$. A prio$r i$, no es un dato que debiera llamarnos la atención, pero encontrar una diferencia tan sustancial entre las obras latinas y las castellanas corrobora nuestra hipótesis de que el marqués del Cenete prefería la lectura y/o consulta de ediciones en dicho idioma que en su lengua materna. De hecho, las ediciones castellanas son obras de

5. Dicha cantidad corresponde a las siguientes entradas $\mathrm{n}^{\mathrm{o}}: 3,5-22,26,28,30-55,59-151,153-$ 156, 158-203, 205, 207, 214-216, 218, 221, 222, 224, 226, 230-232, 235, 238, 241-395, 397-414, $416-437,439-572,609$ у 622.

6. Ejemplo de ellos son los registros $\mathrm{n}^{\mathrm{o}} 27,209-211,213,217,219,220,223,227-229,233$, $239,436,573-575,580,582,586,588,595-598,601-603,605,605$ bis, 606, 608, 612, 617, 619 y 620 . 


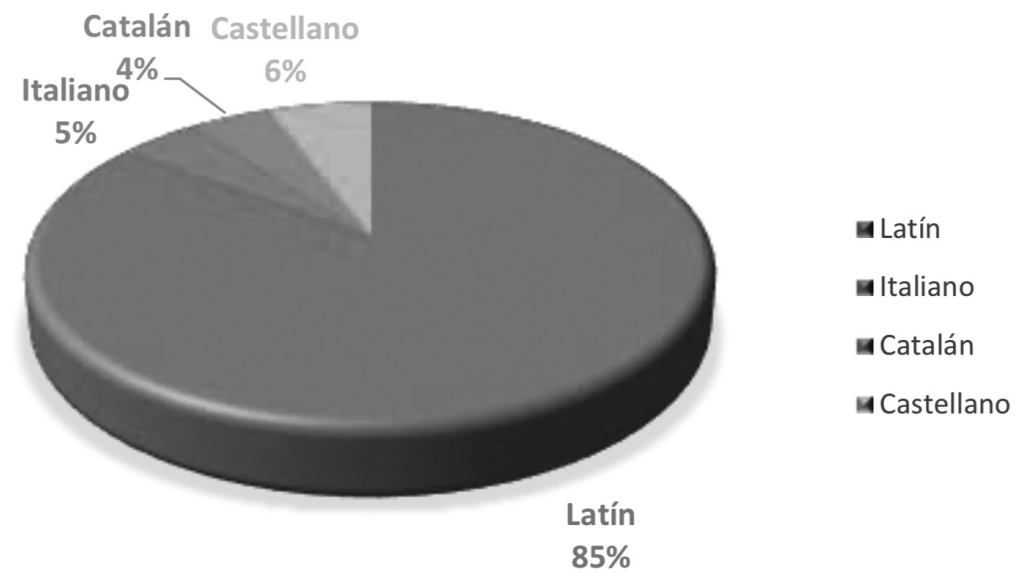

Gráfico 1. Las lenguas.

referencia de Antonio de Nebrija, crónicas de reyes y reinados, etc., pero, además, un ejemplar de los proverbios del marqués de Santillana, su abuelo. Y, del mismo modo que hemos comentado en los ejemplares en latín, en esta ocasión también encontramos ( $\mathrm{y}$, más adelante, comentaremos) tanto ediciones anteriores al fallecimiento del prelado como posteriores a este $\mathrm{y}$, por ende, probablemente adquiridas por el del Cenete, lo que sigue apoyando nuestra teoría de que Rodrigo de Mendoza era un hombre instruido y se decantó no solo por conservar la biblioteca iniciada por su padre sino por acrecentarla y mejorarla sustancialmente.

Eso sí, volvemos a hallarnos con la problemática generada a raíz de ambigüedades dadas entre la información proporcionada por el notario y la identificación realizada por Sánchez Cantón o, incluso, entre dicha información y el título original que hemos corroborado a través de la identificación de la misma en el inventario. Ejemplo de ello son, verbigracia, $\operatorname{los}^{\circ} 573$ y 574, puesto que el registro ofrece un título en catalán, pero ciertamente su título completo y real muestra que la lengua utilizada para la redacción de la mencionada obra es el castellano.

Asimismo, también atesoró obras en italiano (toscano) y en catalán. Respecto a los ejemplares en la lengua de Petrarca, encontramos un total de 30 volúmenes ${ }^{7}$, pero no todos ellos son seguros, puesto que, tal y como hemos comentado unas líneas más arriba, los $n^{0} 33-55$ son pequeñas obras poéticas tanto latinas como italianas, hecho por el cual nos es complejo determinar con exactitud cuántas corresponderían al toscano. El resto de los ejemplares, por el contrario, son detallados por Jaume Bonavida, quien optó por especificar, afortunadamente, las lenguas en las que estaban escritos algunos de los manuales (siempre que difirieran del latín). Por otro lado, resaltamos los libros en catalán $\left(28\right.$ ejemplares $\left.^{8}\right)$ por varios motivos: en

7. Dichos registros corresponden a $\operatorname{los}^{\circ}$ 33-55, 343, 396, 438 y 613-616.

8. Se pueden comprobar en las entradas $n^{\circ} 2,4,206,208,212,234,576-581,583-585,587,589$, $591-594,599,600,604,607,611,618$ y 621 . Quizá la escasa presencia de libros en catalán se debiera, 
primer lugar, porque, por los años de edición, casi la mitad de los que hemos podido identificar son posteriores a $1495 \mathrm{y}$, por ende, fueron adquiridos por el marqués.

Esto nos genera dos hipótesis totalmente contrapuestas: por un lado, que el cardenal Mendoza adquiriera obras valencianas que eran de su interés bien fuera por la temática (generalmente religiosa) o por la trascendencia que tuvo la obra en cuestión (por su materia, por sus grabados, por su autor, etc.), y cuya iniciativa continuaría Rodrigo de Mendoza aprovechando su estancia en el Reino de Valencia y, probablemente, bien asesorado por el entorno social y cultural del que formaba parte (encabezado por el conde de Oliva). Esta primera teoría estaría respaldada, además, por el hecho de que la mayor parte de esos 28 ejemplares se concentran en la última parte del inventario, por lo que, seguramente, se hallarían en la misma caja guardados en el momento del inventariado. ¿Podríamos considerar esta circunstancia como un indicio de la indiferencia del marqués hacia la lengua catalana? ¿O bien podría tratarse de una mera casualidad, puesto que, teniendo en cuenta que el marqués no residía demasiado tiempo en ninguna de sus posesiones y tenía sus bienes preparados para ser trasladados en cualquier momento? La otra hipótesis, en cambio, mostraría una personalidad polifacética y plurilingüe del aristócrata, quien, a través de su itinerario por todo el territorio hispano e incluso italiano, forjó su interés hacia la lengua nativa de cada territorio. Quizá no lo dominara, quizá simplemente lo llegara a entender, pero de alguna manera haría muestra de su acercamiento a la lengua no sólo a través de su colección, sino también a través de su relación con el mencionado reino en general $\mathrm{y}$, finalmente, con los agermanados en particular. Quizá podríamos sobreentender que, en el caso de sí conocer el catalán, los libros en esta lengua no fueran precisamente a los que más estima tuviera (no así como los dos ejemplares de Eiximenis, los cuales fueron registrados en su propia habitación del palacio arzobispal, hecho por el cual podemos destacar que si no eran de su lectura diaria, sí eran de los de más valor -no podemos concretar si sentimental-, puesto que son ediciones que pudo haber adquirido el cardenal Mendoza (1483 y 1484)), pero sí tenía interés e incluso pudieron servirle de lectura en algún momento.

Así como Sánchez Cantón ${ }^{9}$ afirma que las cajas que se hallaron en el castillo de Ayora no fueron nunca abiertas por el del Cenete, ya que fueron enviadas allí

entre otros motivos, a los expuestos por Berger 1989, p. 53: "Les publications dans le langue locale avaient été florissantes pendant les trente premières années de l'installation de l'imprimerie dans la capitale. Le fléchissement observé à la fin de cette période s'était transformé brutalment en débâcle après 1510 , tandis que le castillan connaissait un essor tout à fait remarquable".

9. Sánchez Cantón 1942, pp. 26 y 28: "Los libros inventariados formarían en su mayor parte la biblioteca del Gran cardenal de España, don Pedro González de Mendoza, padre del marqués del Cenete. [...] Muerto el cardenal, tal vez se transportaron desde la casa que tenía en Guadalajara [...] al castillo de Ayora, y allí permanecieron muchos de ellos en cajones que no mandó abrir su heredero [...]". Pero, si el notario encontró 12 cajas en el palacio en el momento del inventariado, dentro de los cuales había obras que solo el marqués pudo adquirir, ¿cómo va a ser factible la hipótesis de que no se dignó a abrirlos una vez recibidos directamente de su padre? Es obvio que no todos los libros serían adquiridos por el marqués, muchos les serían donados, pero, aunque es evidente que Rodrigo de Mendoza sí mostró interés por su colección bibliográfica, su colección libraria fuera ciertamente iniciada por su padre o no (a falta de documentación que respalde dicha teoría). Y, a pesar de que es cierto que 
después del fallecimiento de Pedro González de Mendoza, nosotros debemos contradecir dicha teoría por dos motivos fundamentales: primero, porque el marqués siguió adquiriendo diferentes obras desde 1495 a 1523 (según las identificaciones que hemos podido realizar) y, por lo tanto, de conservarse en cajas, sería por sus constantes desplazamientos, no por su indiferencia hacia la colección heredada de su padre; en segundo lugar, porque él residía en el castillo de Ayora con su familia hasta que a su hermano lo designaron virrey y, posteriormente, a él gobernador subrogado, motivos por los cuales este estableció hasta el momento de su muerte en el palacio arzobispal. ¿Y si dispuso todos sus bienes más preciados para ser trasladados a su nueva residencia, pero la conflictiva situación del Reino de Valencia debido a las Germanías complicó dichos planes? ¿O si los agermanados, al saquear su castillo, no hubieran encontrado mayores tesoros dentro de dichas cajas y estas no se hubieran mantenido intactas? Quizá la opción más sencilla y, con seguridad, la más verosímil fuera que Rodrigo de Mendoza, inmiscuyéndose en todos los pormenores de las revueltas, no tuvo tiempo -ni quizá interés- de poder traerse consigo el resto de los bienes que tenía en Ayora. También debemos tener en cuenta que la muerte repentina cortó toda planificación de futuro que tuviera en mente el noble, no pudiendo volver a ninguna de sus posesiones ni a deleitarse con sus preciados bienes (tapices, pinturas, libros, joyas, instrumentos musicales, etc.).

Por último, quisiéramos comentar aquellos ejemplares en los que ni el título en ocasiones mezclando el catalán y el latín, como en $\operatorname{los}^{\circ} 24$ y 25 , o el castellano y el latín, como el n ${ }^{\circ} 57$, por ejemplo, ni el autor mencionado (Dante, Petrarca, Eurípides, etc.) nos proporcionan información suficiente como para poder determinar la lengua de su redacción (pudiendo ser cualquiera de las mencionadas) o bien aquellos libros en los que la ambigüedad da paso a una confusión entre la identificación como obra latina, castellana, catalana o toscana ${ }^{10}$. Sin obviar, por supuesto, lo llamativo que resultan algunas de las identificaciones relacionadas, sobre todo, con posibles ediciones bilingües: sin lugar a dudas el $n^{\circ} 415$, referente a un diccionario griego, seguramente griego clásico-latín (lo curioso, como más adelante trataremos con detenimiento, es que la posible fecha de impresión de dicho diccionario fue 1485; a priori no tiene por qué sorprendernos, por el contexto pudo haberlo adquirido el cardenal para que su hijo siguiera con la afición por la tradición clásica facilitándole la lectura directa del texto en la lengua original y no así una traducción, pero también puede tratarse de una edición que, por su valor, por su calidad, etc., fuera comprada ex professo por Rodrigo de Mendoza para disipar cualquier tipo de duda generada a raíz de la lectura de las ediciones, quizá, bilingües ${ }^{11}$.

\footnotetext{
"Tanto el entorno de los bienes en los que se enmarcan los libros como el lugar en el que se encuentran [...] proporcionan una información sobre el propietario [...] y [...] también [...] el uso del libro", pero, en ocasiones, “[...] la documentación [...] puede sorprender a la lógica [...]” (Pedraza Gracia 2015, pp. 29-30) y llegar a mezclar, como en el caso del marqués del Cenete, joyas, telares, tapices, vajillas y libros en una misma caja.

10. Dichos ejemplares serían los registros $n^{\circ} 23-25,29,56-58,152,157,204,225,236,237,240$, $579,590,610$ y 623-631.
}

11. Como, por ejemplo, las entradas $n^{\circ} 186,258,309,405$ y 353. 
1.2. Manuscritos y libros impresos.

En el siguiente apartado, analizamos qué tipo de ediciones pudo poseer el marqués del Cenete. De antemano, puede parecer un análisis irrelevante, sin embargo, a través del soporte de dichos volúmenes podríamos esclarecer con toda la seguridad hasta qué punto la biblioteca pudo ser iniciada, efectivamente, por el cardenal Mendoza y en qué medida la amplió su hijo.

Obviamente, estamos ante una excelente biblioteca a tenor no sólo de sus cuantiosos ejemplares (653) sino también por la cantidad de incunables y post-incunables, además de manuscritos concretos que pudo atesorar Rodrigo de Mendoza.

De este modo, comentaremos en primer lugar los posibles incunables, entre otros motivos porque en la mayoría de casos (como podremos comprobar en la identificación) tuvieron una única edición entre 1450-1500 (el propio Jaume Bonavida se encargó de especificar cuál era la tipografía de cada entrada; en consecuencia, de haberse tratado de un manuscrito, lo hubiera anotado), aunque también, debido a la escasa información proporcionada en el inventario, en otros ejemplos hemos planteado diferentes identificaciones, puesto que una misma obra o autor, dependiendo del registro realizado y del detallismo ofrecido por el notario, podrían corresponderse con diversas ediciones (ya se trate de incunables o post-incunables) siempre teniendo como margen el año del fallecimiento de Rodrigo de Mendoza (1523). Tratándose de hipótesis, proponemos que, de las obras identificadas a través del inventario, un total de $227^{12}$ serían incunables. Ahora bien, ¿todos los incunables fueron adquiridos por Pedro González de Mendoza? ¿Pudo haber comprado el I conde del Cid ciertas ediciones en concreto, aunque su año de edición fuera anterior a 1495, es decir, al óbito de su progenitor? Cabe suponer que sí, aunque no tenemos la certeza de poder determinar con exactitud cuáles fueron adquiridos por González de Mendoza (sobre todo por no contar con albaranes que certifiquen la compra de dichos ejemplares por parte del primado y tampoco dejar constancia de ellos en su testamento). También es menester comentar que todos y cada uno de los incunables entre 1495 y $1500^{13}$ fueron adquisiciones realizadas exclusivamente por el marqués, puesto que su padre ya había fallecido.

12. Como así lo ejemplifican los registros $n^{\circ}: 2,4,16-19,28,31,59,63,66,70,71,73,75,77$, $78,81,85-87,90,99,103,114,120,122,123,124,126-130,133,137,139,141,142,144,155,156$, $161,166,168,170,178,179,181,184,197-200,207,210,211,213,220,221,224,227,228,232$, $233,235,238,239,243-249,252,255,256,260,272-279,283,284,290,294,296,297,301,303$, 306-308, 310, 313, 316-318, 320, 321, 324, 328, 329, 335, 338, 342, 348-350, 353, 355, 359-361, 366, 372, 373-377, 382-387, 397, 400-404, 408, 410-417, 419, 423, 429, 430, 432, 436, 438, 444, 446, 447, $450-453,455,460,461,464-468,470,471,474,475,478,479,483-485,492-494,496,499,501,502$, $504,512,514,516-527,529-531,539,540,541,543,545,548-559,561,563-566,570,571,573,575$, $581,584-587,593,594,596,597,604,607,611,620$ у 621.

13. Es el caso de los registros $n^{\circ}: 16$ (1499), 31 (1497), 73 (1500), 115 (1495 o 1497), 124 (1496), 128 (1496), 130 (1499), 133 (1496), 211 (1498), 213 (1500), 222 (1495-1496), 239 (1499), 248 (1495), 273 (1499), 275 (1496), 316 (ca. 1500), 360 (1495), 384 (1498), 436 (1500), 438 (1498), 444 (1496 o 1499), 446 (1496), 453 (1496), 478 (1499), 479 (1495), 520 (ca. 1500), 539 (1498), 543 (1498), 566 (1497), 573 (1498), 594 (1496), 597 (1499) у 621 (1498). 


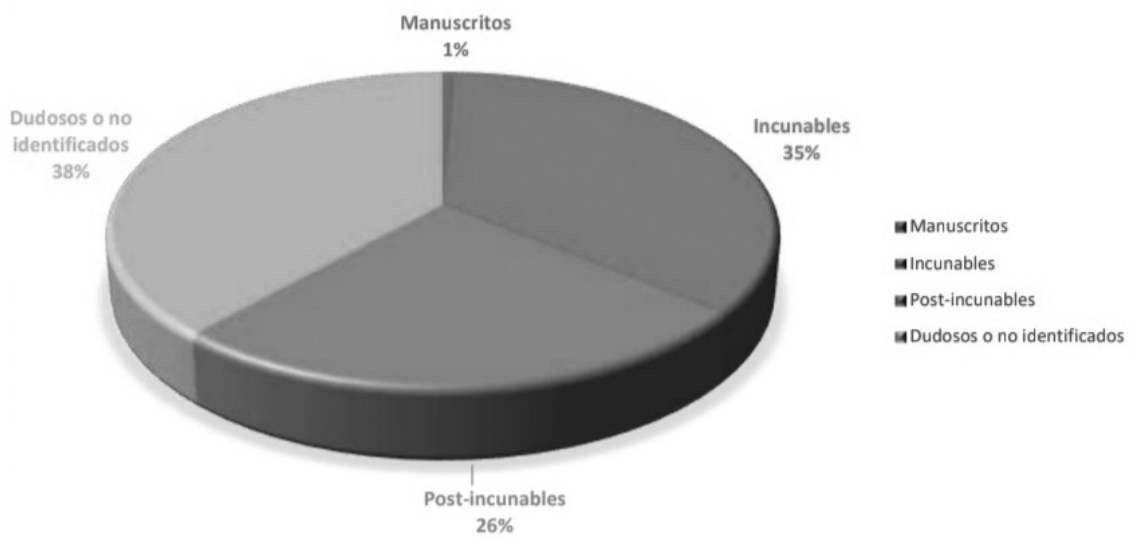

Gráfico 2. Manuscritos y libros impresos.

$\mathrm{Si}$, además, tenemos en cuenta que, aunque el porcentaje de los incunables es el mayor, una parte de ellos no formó parte de la posible herencia del mitrado, ¿hasta qué punto fue iniciada la biblioteca por el cardenal, como propone Sánchez Cantón? ¿Cómo podemos determinar este hecho a falta de más documentación que lo acredite? El hecho de que, de esos 227 ejemplares, 33 son posteriores a 1495, nos da a entender que, de ser la totalidad de los 194 volúmenes restantes comprados por González de Mendoza, sí que le debió proporcionar a su primogénito una notable colección (comparable a la de cualquiera de los nobles castellanos coetáneos de Rodrigo de Mendoza). Pero sí lo hizo, además de completarla con todo tipo de ediciones, encuadernaciones, lenguas, autores y temáticas. Si era un hombre dado a las armas, cuyos objetivos vitales estaban más relacionados con la belicosidad que con la cultura, ¿qué razón le guiaba para adquirir más del triple de las posibles obras que heredó de su padre? Seguramente se tratase de un fin meramente ostentoso: destacaba en bienes inmuebles, muebles, tapices, joyas, instrumentos musicales, vajillas, etc., una nutrida biblioteca imposible de comparar con la de ningún otro noble del momento podía mostrar públicamente no sólo su poder adquisitivo sino también la impresión de un hombre con un gran bagaje cultural. Pero, ¿y si ciertamente era un hombre lector y cultivado, sensible a la cultura de la época, apasionado del arte renacentista y, seguramente, cercano al movimiento humanista? Si no, ¿por qué se aparecen las partidas en las que encargaba ex professo que le compraran tales ediciones de Petrarca o de Dante ${ }^{14}$ y se repitan en

14. Por lógica, hay que tener presente que, teniendo en cuenta que gran parte de su colección fue adquirida por el propio marqués, otras manos intervendrían en dicha encomienda. Es evidente que el marqués deseaba que ciertas obras formaran parte de su colección, por lo que él (al igual que otros nobles de la época) se sirvió del conocimiento de otros para completar su biblioteca (protonotarios, secretarios y letrados en general que fueron, en muchos casos, quienes localizaron, consiguieron y tradujeron las obras por las que el marqués como tantos otros mecenas castellanos se interesaban). De 
varias ocasiones en el inventario? ¿Sólo por el afán coleccionista? Tendría que, al menos, saber de Petrarca y Dante y de lo que, por ejemplo, suponía el primero para interesarse en poseer sus obras y sus diferentes ediciones. Asimismo, y recogiendo el razonamiento del subapartado anterior, tendría que haber tenido un conocimiento considerable del latín para no hallar diccionario alguno de esta lengua al castellano, al contrario que su padre. Aunque bien es cierto que hay más de medio centenar de obras con comentarios, algunos registros lo especifican directamente y en otros no, pero la identificación a través del inventario realizada no deja lugar a dudas de que se trata de ediciones comentadas. ¿Esto nos indica que el noble tenía algún tipo de dificultad con ciertos autores latinos clásicos como pudieran ser, entre otros, Salustio ( $\left.n^{\circ} 331\right)$, César ( $n^{\circ} 416$ y 429), Lucano $\left(n^{\circ} 459\right)$, Terencio $\left(n^{\circ} 173\right.$ y 362$)$, Ovidio ( $\left.n^{\circ} 322\right)$ y Horacio $\left(n^{\circ} 312\right.$ y 314$)$, y por ello requiriera de manuales comentados para su mejor entendimiento? O lo que es lo mismo, ¿quizá la historia, la épica, la tragedia y la poesía latinas revestían cierta dificultad para el marqués del Cenete? ¿O sencillamente se trataban de ediciones comentadas que no tendrían relación aparente con la comprensión lectora de Rodrigo de Mendoza sino más bien con el tipo de lectura más frecuente en la sociedad de su tiempo? Ciertamente, hallamos ejemplares que demuestran que no son comentarios al uso, es decir, que no eran añadidos a la obra original de cualquier autor clásico, sino que vislumbran la realidad de autores como Marsilio de Inghen ( $\left.\mathrm{n}^{\circ} 85\right)$ o Elio Antonio de Nebrija ( $\mathrm{n}^{\circ} 181$ ), que publicaron sendos estudios con comentarios sobre obras de Aristóteles y Persio. ¿Cabría la posibilidad, pues, de que alguna de esas obras sí que correspondiera con una carencia en la comprensión de la lengua de Virgilio por parte del I conde del Cid al igual que la que tuvo su abuelo el marqués de Santillana? Quizá, pero, ¿no es una cantidad de obras comentadas/glosadas prácticamente irrisoria (43 en total) ${ }^{15}$ en comparación al resto de volúmenes en

hecho, según nos transmite March 1951, pp. 58-59, en marzo de 1512 hubo diferentes partidas de libros que el marqués encargó a Enrique Barberá comprar al librero Gaspar Trincher; lo interesante de estas es el hecho de que en dos de los ejemplares cita su autoría, circunstancia que, aunque no nos facilita, a priori, la tarea de identificación, sí que fueron incorporados a la biblioteca por el marqués y no por su progenitor ("[...] pagar a Gaspar Trincher, librero, siete libros y cinco sueldos y ocho dineros [...], es a saber, tres libros de Dante y uno de Petrarca pequeños ligados en oro que costaron a medio castellano cada uno, e por dos libros grandes el uno de Dante y otro de Petrarca con comento ligados en la manera susodicha a treinta y cinco sueldos cada uno [...]"). El autor también cita una partida de marzo de 1500 en la que se estipula qué se tenía que enviar a Valencia para el marqués: "[...] primo, hun vibriario de pergamino de molde de Sant Gerónimo de los que han fecho stampar los frayles de la misma orden y son con istorias de oro y de colores, como si fuessen de pluma". Por otro lado, Gil Fernández 2003, p. 37, asegura que el 13 de octubre de 1513 el marqués del Cenete envió a mossén Gualbes unas Metamorfosis de Ovidio (véase la entrada $\mathrm{n}^{\circ} 585$, en la cual se especifica claramente que la encuadernación es de pergamino) y un De officiis de Cicerón (véanse las entradas $n^{\circ} 172$ y 426, aunque en ninguna de ellas se determina qué tipo de encuadernación tiene) para que se los encuadernase en vitela, y que el 28 de febrero de 1514 Enrique Barberá, su mencionado tesorero, pagó al librero valenciano Antonio Cerdá trece ducados por once volúmenes que contenían los sermones de Nicolò y el Jacobo, De partibus (en el inventario sólo aparecen 4 volúmenes; véanse las entradas $n^{\circ} 384,385,386$ y 387) para enviarlos al licenciado Pisa.

15. Ediciones anteriores al fallecimiento de González de Mendoza (enero de 1495), hallamos los registros $\mathrm{n}^{\circ}$ : 105 (una de las identificaciones realizadas podría tratarse de una obra comentada por 
latín que no le reportaron, de antemano, ninguna dificultad? Y ¿no es probable también que, el hecho de no hallar diccionario en latín alguno secunde la hipótesis de que tenía una buena formación en dicha lengua?

Nosotros consideramos que era un hombre que sabía latín y que era un apasionado de la corriente artística proveniente de la península itálica, cuyas ansias de potenciar su curiosidad cultural y entrar en contacto con libreros, poetas, profesores del Estudi General de Valencia la satisfizo a través de Serafí de Centelles, su amigo.

Por otro lado, aunque en menor medida, son interesantes los manuscritos que poseyó Rodrigo de Mendoza. A pesar de que sólo en uno de ellos ( $\left.\mathrm{n}^{\circ} 57\right)$ se menciona que está "scrit de mà", el resto, a pesar de ser mayoritariamente dibujos, también tendrían anotaciones, puesto que $\operatorname{los}^{\circ} 23$ y 29 son libros de "deboxos", de los cuales uno se correspondería, seguramente, con el Codex Escurialensis $28-I I-12^{16}$ y el n ${ }^{0} 240$ son trazas de las casas de Granada propiedad del marqués.

Asimismo, hay que tener en suma consideración los post-incunables fechados entre 1501 y 1523, ya que abarcan el segundo grupo más notable de la colección (164) y de los cuales la certeza de que fueron adquiridos en su totalidad por el noble es absoluta ${ }^{17}$. Reiteramos la idea de que partimos de hipótesis desde la propia identificación, ya que el notario llega a perfilar en muy pocas ocasiones características de la edición.

Por último, mencionaremos que, desafortunadamente, por escasez de información ha habido registros muy difíciles de determinar a qué obra se refiere el notario (quien, con frecuencia, se equivoca en la transcripción llevando a confusión en su posterior lectura), no hemos identificado y, por otro lado, ha habido otros que, a pesar de sí haber podido identificar, la gran variedad de ediciones que del autor en cuestión o de la obra citada existen, nos imposibilita la adecuada identificación.

pseudo Aristóteles), 141, 181 (a pesar de que la primera identificación realizada data de antes de 1495, hay otra identificación posterior comentada por Nebrija), 207, 224, 257, 301, 317, 321, 461 y 516. Posteriores a dicha fecha y, con toda seguridad, adquiridos exclusivamente por el marqués, son las entradas $n^{\text {o: }}: 14,15,21,85,173,194$ (podría ser de ambas fechas), 312, 314, 322 (de todas las obras propuestas para identificar dicho registro, es cierto que sólo una correspondería a un ejemplar comentado), 328, 459, 463, 467, 489, 502, 525 y 543. Asimismo, tenemos constancia a través del testimonio del notario que hubo más obras comentadas, pero que no hemos podido identificar: $n^{\circ} 200,330,331$, $343,354,372,416,429,613$ у 614 .

16. Cf. Fernández Gómez 1992, pp. 123-162; 2000, pp. 30-43; Falomir Faus y Marías 1994, pp. 101-108; Scaglia 2004, pp. 373-383; Marías 2005, pp. 14-35.

17. Corresponden a los registros $n^{\circ}: 14,15,21,22,26,27,30,60-62,69,72,78,80,91,95,98$, $102,111,112,119,132,136,143,146,154,158,160,163,165,167,169,171,173,174,176,180,186$, $192,195,196,201,205,212,214,218,219,223,229,234,250,251,254,258,259,261-271,276,291$, $299,302,311,312,314,322,323,326,327,330,336,337,340,341,344,346,347,351,352,356,362$, $364,365,371,378-381$ bis, 388-392, 395, 396, 398, 405, 424, 433-435, 442, 454, 456, 458, 459, 472, 473, 477, 480, 486, 489-491, 497, 498, 503, 505, 508, 510, 511, 536, 537, 544, 546, 547, 552-555 bis, $567,569,574,576-578,582,583,588,589,595,598-601,603,605,606,608,609,617,619$ y 622. 


\subsection{La encuadernación}

A continuación, expondremos el tipo de encuadernación ${ }^{18}$ de cada ejemplar de la biblioteca, siempre y cuando el notario nos proporcione dicha información a lo largo del registro.

Tabla 1. la encuadernación

\begin{tabular}{|l|c|}
\hline Quadernat en post(s) / 'ligat en post(s) & 16 \\
\hline Cuberts de pergamí / quadernat en pergamí / ligat en pergamí & 59 \\
\hline Aluda vermella & 3 \\
\hline Cuyro & 42 \\
\hline Setí negre & 1 \\
\hline Blanca vella & 1 \\
\hline Aluda verda e vella & 1 \\
\hline Setí carmesí ab tiretes de burell & 1 \\
\hline Sin descripción en el inventario & 503 \\
\hline Quadernat en paper engrutat / ligat en paper engrutat & 26 \\
\hline
\end{tabular}

A primera vista, observamos que $3 / 4$ partes del total de libros no contienen ningún detalle o explicación alguna referente a su encuadernación y al tipo de soporte utilizado para su edición (papel o pergamino). Por otro lado, sí que nos informa de detalles muy particulares sobre algunos de los volúmenes que se va encontrando a medida que va abriendo las cajas en las que se hallaban. De estas obras, que no llegan a 1 $1 / 4$ del total, nos sorprende la variedad de decoración en la encuadernación, generalmente de pergamino, y la minuciosidad con la que la describe Jaume Bonavida en contraposición al resto de ediciones.

A pesar de que los revestimientos librarios eran muy estimados por la aristocracia como reflejo de su estatus y poder ${ }^{19}$, de las descripciones realizadas, el mayor número de ejemplares (un total de 94) con la misma apariencia física es el referente a la encuadernación en vitela ${ }^{20}$, la más modesta, de hecho, en el proceso de comprobar las diferentes obras registradas en el inventario hemos encontrado ejemplares que, en el marco temporal en el que nos movemos, representan de forma excepcional la posible edición que guardaría el marqués, puesto que, en algunos casos, sólo hay noticia de una única impresión y, afortunadamente, se conserva su encuadernación en vitela original ${ }^{21}$. Sí debemos remarcar que existe, entre

18. López Serrano 1972, p. 5. Carpallo Bautista 2002, pp. 355-373; 2009, pp. 322-349.

19. Sánchez Oliveira 2017, p. 389.

20. Dichos ejemplares corresponden con los registros $\mathrm{n}^{\circ} 1,14,15,17-21,26-28,30-32,57,59$, $114-115,236-242,345-377,438-439,573-610,617-620$ y uno de los cuatro misales hallados entre otros enseres personales del noble.

21. Como, por ejemplo, las entradas no $581,582,585,596,610$ y 620. 
los volúmenes citados, dos ejemplares en concreto que comparten características con otros apartados: el $n^{\circ} 57$ es el único "scrit de mà" y, aunque el material escriturario es pergamino, está "cubert ab una aluda ${ }^{22}$ vermella"; y el n ${ }^{\circ} 240$, puesto que está impreso sobre pergamino, pero está encuadernado en "post $(\mathrm{s})^{23}$ ".

Por otro lado, y después del pergamino, el siguiente material más representativo (con un total de $72^{24}$ ) entre los ejemplares detallados en el inventario es el cuero. En ciertos casos concretos de las entradas podemos examinar con más detenimiento algunos aspectos: el $\mathrm{n}^{\circ} 16$ sigue el patrón de la encuadernación en cuero, pero está ligado "en paper engrutat ${ }^{25}$ "; el n ${ }^{\circ} 24$ está encuadernado con cuero "burell16"; el no 29 con cuero "tenat ${ }^{27 "}$; $\operatorname{los} \mathrm{n}^{\circ} 33-55$ se caracterizan por estar encuadernados en "paper engrutat", pero cubiertos de cuero rojo (al igual que los registros n $\left.n^{\circ} 206-235\right)$; el n ${ }^{\circ} 116$ se caracteriza por las cubiertas "verdes"; los n 236 y 440 tienen una encuadernación de cuero "vermell e daurat"; los no 439 y 623-631, una de cuero negro; el n $n^{\circ} 613$, puesto que está encuadernado en "post(s)", pero, en esta ocasión, cubierto "ab cuyro vermell ab unes roses de or en la coberta"; el n 614 , sobre el que el notario especifica que contiene unas características similares al anterior número; y, por último, los n⿳0 615-616, de nuevo, están encuadernados con cuero rojo.

Seguidamente, hallamos aquellas obras encuadernadas y/o ligadas en "post(s)" (37 en total $\left.^{28}\right)$, entre las que, del mismo modo que en la característica anterior, observamos seis obras que presentan otros detalles, como, verbigracia: el $n^{\circ} 56$, el ya mencionado $\mathrm{n}^{\circ} 57 \mathrm{y}$ el $\mathrm{n}^{\circ} 58$, los tres están encuadernados en "post(s)" cubiertos de una "aluda vermella" (en consecuencia, aunque en el gráfico aparezca con una representación global del $0 \%$, hay 3 ejemplares que cumplen con dicho detalle); así como también los ya comentados $\mathrm{n}^{\mathrm{0}} 240,613$ y 614 . También hallamos otros ejemplares que, a pesar de estar encuadernados de la misma manera, uno está cubierto con "blava vella" ( $\left.n^{\circ} 611\right)$ y el otro con "aluda verda e vella" ( $\left.n^{\circ} 612\right)$, representando, asimismo, un porcentaje irrisorio, pero no irrelevante, puesto que son ejemplares únicos en toda la biblioteca.

Otro volumen, aunque ignoramos su tipo de encuadernación, sorprende por una apariencia de lo más llamativa y especial, al menos, en comparación a los

22. Una piel suave de oveja (Rodrigo Lizondo 2013-2014, p. 152).

23. "Peça de fusta que servia de coberta a un llibre" (DCVB). Trad.: "Pieza de madera que servía de cubierta a un libro". Petrucci 2011, p. 179.

24. Obras correspondientes a los registros $n^{\circ} 16,24,29,33-55,206-236,439,440,613-616$ y $623-631$.

25. El engrudo es un material adhesivo, obtenido por la cocción de almidones extraídos del trigo, maíz, arroz, tapioca o mazorca (Miguélez González 2009, p. 665). Asimismo, Soriano Roles (2010, p. 1708) comenta que se trata de un tipo de encuadernación más débil, dando a entender, por ende, que su uso era común en la encuadernación tanto de libros manuscritos como en impresos.

26. "Color fosc, com de cendra; intermedi entre negre i blanc" (DCVB). Trad.: "Color oscuro, como de ceniza; intermedio entre negro y blanco".

27. "Color moradenc, vinós o ros fosc" (DCVB). Trad.: "Color cárdeno, vinoso o rubio oscuro".

28. Correspondientes a los registros $\mathrm{n}^{\mathrm{o}}$ 2-4, 29, 56-58, 116-117, 238, 240-242, 378-395, 438, 611-614 y otro de los cuatro misales aparecidos. 
restantes ejemplares: se trata del $n^{0} 622$, puesto que está cubierto de "setí carmesí ab tiretes de burell".

Por último, traer a colación la encuadernación en "paper engrutat" con una presencia total en 26 obras $^{29}$.

A pesar de que los detalles citados por Bonavida debieran de haber sido claves para hallar en las diferentes bibliotecas el ejemplar que pudo haber pertenecido en origen a Rodrigo de Mendoza, el propio paso del tiempo, los cambios de encuadernación, el deterioro, la pérdida de dichos ejemplares, etc., han dificultado mucho el hecho de encontrar una edición que coincida con la descripción del inventario. Eso sí, como ya hemos adelantado, aquellas encuadernaciones de vitela que pertenecen indudablemente a la edición que pudo poseer el aristócrata (que no el ejemplar en concreto), sí que hemos tenido la fortuna de identificarlas y compararlas.

\subsection{Temáticas}

Las temáticas en las que se compone la colección bibliográfica en cuestión es uno de los asuntos que, junto a las lenguas o al tipo de edición, más pueden suscitarnos certezas o incógnitas. Y no (o no en exclusiva) debido a las dificultades generadas por las interpretaciones que de las obras realizó el notario Jaume Bonavida y que, al no ser identificadas con exactitud y veracidad, pueden dar a confusión en cuanto a la temática, sino por lo que respecta a los gustos del marqués del Cenete $-y$, por extensión, de su progenitor-.

A simple vista, lo más llamativo, a nuestro parecer, de los datos expuestos en la gráfica es la sustancial diferencia entre las obras de temática filológica, erudita y/o literaria (192 obras y representando un $28^{\prime} 59 \%$ del total ${ }^{30}$ ) y las relacionadas con el arte militar ( 5 libros y un 0 '79 \% con respecto al total ${ }^{31}$ ). ¿Por qué? Por el hecho del contraste que supone una personalidad como la de Rodrigo de Mendoza, un hombre de armas, que seguramente habría compaginado en su juventud la formación física con la intelectual, quien sería un entendido en armas, así que la escasez en su colección de manuales de esta índole es cuando menos sorprendente. ¿Cómo puede ser que un noble, que -como defendemos- compaginaba a la perfección la faceta bélica con la culta no fuera un apasionado coleccionista de libros sobre estrategias militares, armas, incluso de novela caballeresca? ¿Esa abismal diferencia y la consiguiente poca presencia en su biblioteca no se debería al experimentado manejo que, de las armas y de las tácticas militares, tenía el marqués por lo que no precisó atesorar ningún ejemplar que especificara tipologías, usos, estrategias

29. Los ya mencionados $n^{\circ} 16,24,25$ y 33-55.

30. Todos los registros que se encuadran en esta temática son $\operatorname{los} \mathrm{n}^{\circ} 14,15,24-27,30,33-56,58$, $60,61,73,81,86,115,120,132,135,136,140-142,150-152,157,160,164,165,169,173-175,180$, $181,185,193,197-199,201,203,204,207,216,220,221,223,225,226,229,235-237,239,241-243$, $253,262,271,303,306$ bis, 307, 308, 311-315, 317, 318, 320-324, 327-330, 332, 335-339, 341-350, 353-356, 358-372, 375-377, 396, 413-415, 417, 423, 424, 427, 434, 438, 439, 459, 463, 545, 567-569, $574,582,585,588,597,601,603,605,605$ bis, 613-619, 623-631 y 9 libros de poesía citados en el inventario entre ropas y enseres personales del aristócrata..

31. Dichos volúmenes corresponden a las partidas $n^{\circ}: 300,351,409,430$ y 501 . 


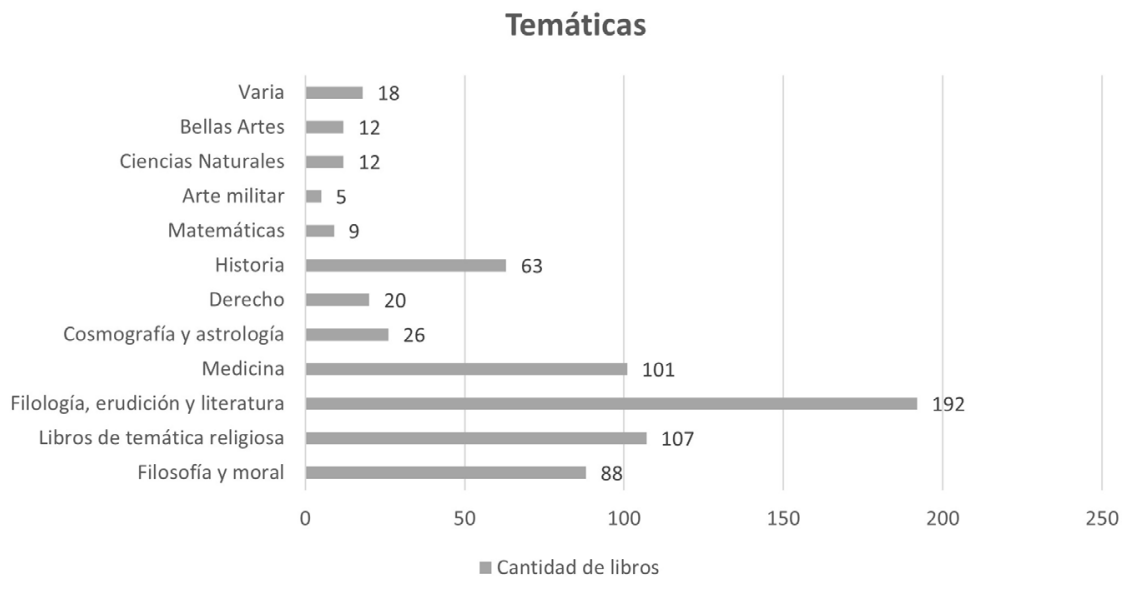

Gráfico 3. Temáticas.

varias, etc.? ¿Para qué poseer libros cuyos conocimientos no necesitaba dada su contrastada experiencia? Por otro lado, ¿no resulta un tanto extraño que un noble, en el ambiente cortesano al que perteneció, no poseyera novelas caballerescas populares tales como Tirant lo Blanch ${ }^{32}$ ? Parece ser que sus gustos, lejos de la banalidad que pudiera suponer desviar su atención hacia pasiones y enredos de este tipo de narrativa, iban más bien dirigidos a formarse siguiendo, a grandes rasgos, las enseñanzas de los autores propuestos por los humanistas (aunque, obviamente, no todos ellos los encontramos en el inventario de sus bienes).

En este sentido, es menester hacer énfasis en aquella temática más del gusto del noble: la relacionada con la filología, la formación de una persona erudita y la literatura, mayoritariamente, clásica. En su colección no faltaban historiógrafos, poetas, dramaturgos, filósofos, médicos, matemáticos, físicos y oradores en mayor medida latinos, pero también griegos; así como algunos de los escritores más representativos del humanismo. ¿La ingente cantidad de libros sobre esta temática indica necesariamente una clara inclinación de Rodrigo de Mendoza hacia este tipo de lectura? En principio sí, pero, ¿y si la mayor parte de estos ejemplares hubieran sido adquiridos anteriormente por el cardenal primado? Sería irrelevante, porque, a pesar de ser así, en el caso de ser cierto, es evidente que el marqués del Cenete amplió también la adquisición de volúmenes de este género, por lo que su interés por la literatura hubiera seguido la estela, en todo caso, de su progenitor.

Aunque heredara ciertos volúmenes de su padre, amplió, tal y como defendemos, todos los ámbitos del conocimiento. De hecho, otra de las temáticas más

32. Aunque bien es cierto que poseía la obra de Maurilianus Pamphilius, De amore, citado entre los precedentes de La Celestina (Sánchez Cantón 1942, pp. 32-33), obra, como ya hemos comentado en otro apartado, no figura en su colección. También hay que recalcar que hablamos de libros poseídos por el marqués, desconocemos si este tipo de literatura formó parte de sus preferencias lectoras. 
representativas en la biblioteca sería la filosófica ( 88 ejemplares y constituyendo un $13^{\prime} 74 \%$ del total ${ }^{33}$ ) y, aunque poseyera manuales de toda índole y autoría, el autor que más se repite, de nuevo, es Aristóteles, otro intelectual clásico que, a través de su reiterada presencia en los bienes del aristócrata, nos vislumbra ese interés por la filosofía aristotélica y por los comentarios que posteriores autores hicieron de las doctrinas del heleno.

Quizá, el dato que más nos extrañe sea el número de volúmenes sobre medicina que coleccionó Rodrigo de Mendoza. Tal vez pudiéramos entender una presencia relativamente considerable de todo tipo de manuales, por cuanto la curiosidad lectora y erudita de un noble como el marqués pudiera requerir, pero no llegar a compararse con el número de obras filosóficas que también poseía. De hecho, hemos detectado hasta un total de 101 posibles ejemplares de diferentes áreas médicas y farmacopeas $\left(15^{\prime} 96 \%\right.$ con respecto a la totalidad de obras $\left.{ }^{34}\right)$, ¿podría deberse al interés médico particular que pudiera haber mostrado el marqués o debido a la salud delicada de su segunda esposa y de su hijo ${ }^{35}$, las epidemias y brotes de peste de este período, las diferentes heridas recibidas en acto de batalla y otro tipo de males comunes que pudo potenciar la adquisición de todo tipo de obras? En este sentido, ¿dónde podría residir la utilidad que pudiera extraer Rodrigo de Mendoza de los estudios, por ejemplo, de Galeno?

No menos importante son las obras de vertiente religiosa (104 ejemplares y abarcando el $15^{\prime} 64 \%$ del total ${ }^{36}$ ). Un noble culto que se convirtió en el perfecto ejemplo del modelo de príncipe que proponían los humanistas pero aplicado a alguien de su estirpe: formado en armas y en las humanidades, estratega y guerrero audaz, conocedor de las distintas lenguas del territorio hispano y del latín, sensible para con la arquitectura y arte italianos hasta convertirse en introductor privilegiado del Quattrocento allá donde vivió, hombre curioso e interesado en los autores clásicos propuestos como lectura propicia para el crecimiento personal y cultural de un humanista en ciernes, y encarnando, asimismo, los ideales del buen caballero $^{37}$. En este sentido, no dejaba de personificar un equilibrio ideal entre el modelo

33. Dichos volúmenes podemos encontrarlos en las entradas $n^{\circ} 79,94,97,105,127,148,159$, $172,178,179,186,187,188,194,224,232,233,258,283,284,304-306,325,326,333,334,373,426$, $428,433,435,443-445,457,460-462,464-469,472-476,478-480,482-493,495-499,502,508,512$, $518,523,528,539,542,560,570,571,575,586,587,589,591,594$ у 598 .

34. Podemos encontrarlos en las partidas $\mathrm{n}^{\mathrm{o}} 1,16,20,28,59,63-72,74-78,80,82,84,85,87-$ $90,92,93,99,100,101,103,107,110-112,114,116,131,138,162,168,184,189,190-192,291$, $378-395,440,441,470,471,503,505,507,510,513-517,519,521,522,524-527,529-535,538,540$, 544,559 у 621 .

35. March 1951, p. 65; Pérez García 2017, p. 120.

36. Los cuales corresponden a $\operatorname{los}$ registros $\mathrm{n}^{\circ} 2,4-13,17-19,62,117,119,121,123,124,126$, 128-130, 133, 139, 149, 170, 176, 196, 217, 244-252, 254-257, 259-261, 263-269, 272-274, 276, 277 , 280-282, 285-287, 293-295, 298, 404, 436, 442, 541, 546-551, 553-555 bis, 562-565, 576-579, 584, $592,600,604,606,607,609$ y 611 , y, además, los cuatro misales y un libro de oro que aparecen también citados en el inventario.

37. Bouza Álvarez 2000, pp. 100-102, detalla que al perfecto caballero había que definir como “[...] esforzado, claro, justo, liberal, católico, fiel, confiado, ingenioso de repente, galán, bizarro, feliz de memoria, prudente, sufridor de intemperies y todas las demás virtudes que cabría imaginar propias de una condición nobiliaria [...]", aunque en la práctica "[...] los caballeros parecen haberse dejado 
propuesto por Maquiavelo (teniendo como patrón a un rey como Fernando el Católico, hábil militar y astuto diplomático) y el defendido por Erasmo (cristiano y culto, además de pacífico). Sus intereses religiosos iban desde poseer ejemplares de los Evangelios hasta tener diferentes ediciones de las Sentencias de Pedro Lombardo (y los posteriores comentarios que a dicha obra hicieron San Alberto Magno, Johannes Major, Gabriel Biel, etc.), así como a Francesc Eiximenis, Pío II, el Cartujano, etc., y varias ediciones de la Biblia (incluso con iluminaciones). Este hecho, a su vez, ¿no nos vislumbraría un espíritu crítico y curioso que buscaría encontrar respuesta a ciertos dilemas consustanciales al ser humano en la lectura religiosa desde las diferentes perspectivas que ofrecerían la variedad de autores identificados? Por último, ¿no resulta, además, un signo claro de su devoción que de los libros hallados en su habitación en el momento de su fallecimiento fueran, en su mayoría religiosos? Es decir, que su consulta, fuera periódica o frecuente, era evidente durante su estancia en el palacio arzobispal de Valencia ${ }^{38}$. Pero no hemos de olvidar que, junto a estos libros citados, hallamos una alta presencia de obras de medicina y de literatura, aunque también, en menor medida, de historia, cosmografía y bellas artes (no así de filosofía, ciencias naturales, derecho, arte militar y matemáticas; circunstancia que nos demuestra que su interés por estas temáticas no eran especialmente tanto de su agrado como los que se llevó consigo a la capital del Turia).

Mas no parecía ser un hombre únicamente interesado en la literatura, la gramática, la medicina y la religión, su otra gran pasión debió ser la historia (con 63 ejemplares y representando un 9 '95 \% de la totalidad ${ }^{39}$ ). Alguien con sus vivencias y sus circunstancias que aspiraba a dejar estela de su fama a la posteridad, debería tener como referente aquellos autores pretéritos que marcaron el devenir de la sociedad y que dejaron, además, su legado por escrito. Quizá Rodrigo de Mendoza viera en César un ejemplo a seguir para llegar a conseguir la fama que este obtuvo, más allá de su tiempo; quizá simplemente era un aficionado a los hitos de Roma explicados por el dictador romano, por Tito Livio o Salustio. Aunque también

llevar más por la furia, rasgo que en absoluto ha de considerarse ausente de su perfil ideal [...]”. De este modo, "[...] enojarse, agraviarse, disgustarse y ofenderse fueron pautas continuas en la conducta caballeresca, quizá porque la supuesta ingenuidad natural de los nobles, en la que tanto insistieron sabedores de que en ella consistía su diferencia esencial [...]", dicha actitud exigía que "[...] se contuvieran en su ánimo y se alteraran hasta la violencia con la cólera que precisa el coraje [...]”. Esta definición parece acoplarse a la perfección a la actitud caballeresca y nobiliaria de la que hizo gala Rodrigo de Mendoza si nos remitimos a su periplo vital y todo lo que aconteció en su contexto.

38. Esta teoría sería corroborada si nos basamos en la opinión de Pedraza Gracia 2015, p. 22: "El libro de rezo u oración [...] presente entre los bienes de casi todos los grupos sociales [...]. Se trata de libros ricos, en muchas ocasiones, con ilustraciones, con encuadernaciones especiales [...]. Son libros de reflexión individual". Además, en derredor de los libros que su dueño llevara consigo en sus viajes, Gonzalo Sánchez-Molero 2015, p. 185, explica que “[...] los libros que aparecen [...] se seleccionaron obviamente para ser leídos, tenían una función específica, ya fuera durante el trayecto, o ya en el lugar de destino".

39. Cuyos registros hallamos en $\operatorname{los}^{\circ} 21,22,57,113,118,125,134,137,144,146,147,154$ $156,158,167,177,195,200,202,205,209,227,228,238,278,288,292,297,299,301,302,316$, $319,331,340,352,403,410,411,416,418-420,425,429,432,437,536,556-558,572,580,581,583$, $590,593,595,596,599,602,608$ у 612 . 
hallamos historiografía más cercana en el tiempo al marqués, de la mano de Lorenzo Valla o de Jehan Bagnyon, demostrando un interés añadido, sobre todo, a los éxitos de Carlomagno, a crónicas del rey Rodrigo, a las genealogías de los reyes de Aragón, y muy particularmente a la historia de Alfonso V el Magnánimo, etc. Tal vez, verse reflejado en grandes figuras de la historia europea era una motivación añadida para la personalidad del noble, con el objetivo de conseguir todos los fines que se proponía en pro de obtener reconocimiento social imperecedero. En este sentido, la notoriedad que pretendía alcanzar, a pesar de todos los altos asuntos y embrollos en los que se inmiscuyó invariablemente, vino de la mano de la eclosión de las Germanías en los últimos años de su existencia, conflicto en el que su implicación tuvo mucho más eco que el de otros nobles valencianos (incluyendo a su hermano, el propio virrey). Al fin y cabo, el que no conoce su historia, está condenado a repetirla. Esto parece ser, por lo que podemos interpretar de su colección libraria, que constituyó el leitmotiv de Rodrigo de Mendoza y por ello se entendería la copiosa sección histórica. Con todo, es curioso que no hallemos ninguna referencia bibliográfica a los Reyes Católicos y sí a otros gobernantes de la Corona de Aragón, quizá esta carencia estuviera motivada por la mala relación que, a partir del óbito del cardenal, empezó a fraguarse entre ellos.

Para finalizar, pero no por ello de menor relevancia, otras secciones que tuvieron menos presencia en la colección: bellas artes (12 obras y abarcando el 1'98 \% del total ${ }^{40}$ ), ciencias naturales (12 ejemplares y con también un 1'98 \% $\%^{41}$ ), derecho (20 libros y un 3'16 \% ${ }^{42}$ ), cosmografía y astrología (26 obras y un 3'94 \% ${ }^{43}$ ), matemáticas ( 9 ejemplares y un 1' $42 \%{ }^{44}$ ), y, en último lugar, obras de otra índole que hemos aunado en la sección varia (18 obras y un 2'84\% de la totalidad de la colección $\left.{ }^{45}\right)$.

En el caso de las bellas artes, generalmente engloban dos áreas bastante marcadas: la música y la arquitectura. Algunas de las obras musicales, por la confusa información del registro en cuestión, no las hemos podido identificar, y, por lo tanto, no hemos podido determinar si fueron compradas por el marqués o por su padre (hecho que, a su vez, nos mostraría un gusto musical de Rodrigo de Mendoza), aun así, es cierto que dos volúmenes ejemplifican claramente un interés por la obra de Gaffurio ( $\mathrm{n}^{\circ} 230$ y 231 ). Por otro lado, la pasión por la arquitectura del marqués fue más que obvia (habida cuenta de las reformas de las casas de

40. Ejemplo de ello son los registros $n^{\circ} 23,29,208,215,230,231,240,357,374,407,408$ y 509.

41. Tal y como se puede comprobar a través de $\operatorname{los} \mathrm{n}^{\circ} 145,153,279,310,397,399,402,458$, $520,537,617$ y 620 .

42. Así como podemos observar en los registros $n^{\circ} 83,122,155,166,171,206,210,212,213$, 222, 270, 275, 290, 296, 400, 401, 412, 511, 552 у 610 .

43. De esta temática, hallamos $\operatorname{los}^{\circ} 3,32,91,95,98,108,109,143,289,309,398,405,446$, 447, 449-456, 485 bis, 500, 504 y 566.

44. Los cuales corresponden a los registros $n^{\circ} 104,106,163,214,219,406,477,481$ y 494.

45. Cuya presencia hallamos en las entradas $n^{\circ} 31,96,102,161,182,183,211,218,234,421$, $422,431,448,506,543,561,573$ y 622 . Esta categoría la hemos denominado "varia" por contener obras de temática totalmente heterogénea y no encasillable en otras categorías como, verbigracia: práctica de escribir o el arte de escribir, manuales contra el mal de ojo, etc. También engloba aquellos registros notariales que contienen dificultades de interpretación y, por tanto, de identificación. 
Granada, Ayora, pero, sobre todo, La Calahorra), es por ello que los tratados de Vitruvio y Alberti ${ }^{46}$ llaman poderosamente la atención y apoyan la teoría de que el marqués fue un gran admirador de la arquitectura renacentista, plasmada en el citado Codex Escurialensis 28-II-12 $2^{47}$ (el cual podría corresponderse con los n 23 o 29), álbum de dibujos de autor que seguramente adquirió en uno de sus viajes a Italia -probablemente el último-, y utilizado recurrentemente en su palacio de La Calahorra de la mano de Lorenzo Vázquez y, sobre todo, de Michele Carlone y sus colaboradores italianos. Esta última teoría estaría respaldada por el hecho de hallarse dicho álbum en la habitación del fallecido Rodrigo de Mendoza en el momento de iniciar el inventario; es decir, que para él tendrían un alto valor sentimental o económico (ambos totalmente ciertos, puesto que el mencionado Codex era un volumen único, muy posiblemente un álbum de autor).

No sabemos hasta qué punto los estudios de ciencias naturales eran del agrado del noble, entre otros motivos porque la ingente mayoría de las obras de esta temática pertenecen a Plinio el Viejo y a su sobrino Plinio el Joven, con ediciones que no hemos podido acotar lo suficiente como para determinar si pudieron formar parte de la biblioteca iniciada por el cardenal o ampliada por el marqués. Lo que sí debemos comentar a ciencia cierta es que hay una serie de autores de esta índole que, si no fueron del particular interés de Rodrigo, al menos formaron parte de su colección a partir de 1495 (Columela, Jean de Jandun, Avicena, Gabriel Alonso de Herrera y Bartholomaeus Anglicus).

Asimismo, otro género interesante es el del derecho. Pues no sólo poseyó ejemplares de los Decretales y otros manuales jurídicos, sino que, lo que es más atrayente, adquirió, además de obras de William of Ockham y Guillaume Budé, volúmenes referentes a la jurisdicción del Reino de Valencia (nº 206 y 270), por lo que, residiendo en su demarcación, y dado su historial de abusos a sus trabajadores y diversos conflictos políticos y familiares en los que se involucró, sería entendible que estuviera informado de sus leyes.

A pesar de poder englobar la cosmografía y la astrología dentro de las ciencias naturales, hemos optado por separarlas por tratarse de unos volúmenes que fueron añadidos a la colección por el mismo Rodrigo de Mendoza; de hecho, parece ser que uno de los tratados que más eran de su agrado era el de Ptolomeo, tal vez también por las exquisitas xilografías (iluminaciones no creemos, puesto que sólo tenemos constancia de un manuscrito en su biblioteca, como ya hemos comentado) que sus ediciones tendrían, ya que poseyó hasta 3 ejemplares. Además, por lo general, sus intereses se inclinaban más por cuanto concernía al planeta y su formación que a los astros. ¿Tenía aspiraciones transoceánicas y nuevas expectativas

46. Aunque hemos encontrado ediciones tanto anteriores al fallecimiento del arzobispo de Toledo como posteriores; bien es cierto que las identificaciones propuestas podrían tener dos posibilidades: haber sido adquiridas por González de Mendoza y su lectura y consulta motivara ese pujante interés de nuestro protagonista, o haber sido compradas ex professo por el marqués a sabiendas del valor que estas obras pudieran tener y de los conocimientos que de ellas pudiera sacar y volcar en el ideario arquitectónico que tenía pensado poner en práctica en sus bienes inmuebles.

47. Véase la nota 16. 
por lo que el conocimiento exhaustivo de la Tierra y, también, de su geografía le eran de importancia? ¿Pretendía, tal vez, convertirse en un modelo de noble valeroso en la guerra, ávido coleccionista, generoso mecenas y vocación erudita (teniendo nociones de todas las áreas posibles de conocimiento)? ¿O simplemente se trataba de una coincidencia pues, quizá, esos ejemplares llegaron fortuitamente a su colección a través de agasajos de aquellos que querían formar parte de su círculo más cercano?

En el caso de las matemáticas, podríamos teorizar que la escasa presencia de obras de esta temática se debiera a un menor interés del marqués del Cenete por esta disciplina, pero si, de los 9 volúmenes, 7 son ediciones posteriores al fallecimiento del cardenal y todos relacionados con la aritmética y la proporción, ¿no estaría estrechamente relacionado con la pasión que sentía por la arquitectura, también con la pintura, y sus ansias por dominar un campo como el mencionado requería de conocimientos básicos de las matemáticas? ¿Podría ser que tal obcecación por la arquitectura renacentista propiciara que las casas que tenía ideadas en Granada y en Coca no se llevaran a cabo o que acabara enfrentándose con Lorenzo Vázquez e incluso encarcelándolo ${ }^{48}$ porque las reformas de La Calahorra no se adaptaran a sus criterios italianizados?

En último lugar, hemos englobado diferentes obras misceláneas (como, por ejemplo, la obra de Antonio Tibaldeo en el registro ${ }^{\circ}$ 438, la de Girolamo Balbi en el $n^{\circ} 506$, o la de Boecio en el no 561), de temáticas diversas que no encuadran en ninguna de las demás disciplinas (es el caso del comentario de Petrus Torrisanus en la entrada $n^{\circ} 543$ ) o que, también, han podido generarnos algún tipo de duda: tales como dos manuales para saber escribir correctamente ( $n^{\circ} 96$ y 234 ; obras que, a su vez, nos transmiten una posible afición del marqués por tener una caligrafía impecable, acorde a su rango y a su linaje y al tipo de noble que aspiraba a ser), sobre el viaje a Tierra Santa $\left(\mathrm{n}^{\circ} 211\right.$ y 573$)$, etc.

\subsection{Los autores y las lecturas}

El objetivo de este penúltimo apartado, además de aunar la autoría de todas las obras identificadas, es llegar a la conclusión de cuáles fueron los autores más frecuentes en su colección para poder sacar alguna conclusión reseñable.

Como preámbulo, debemos comentar que, desde la perspectiva del análisis de cualquier biblioteca particular, parece que, de antemano, el número de libros ha de ser indicativo en mayor medida de la capacidad adquisitiva del propietario que del interés sobre los temas que se incluyen en la misma, ya que cuanto mayor sea la capacidad adquisitiva más se pueden ampliar los intereses y, a la inversa, es muy difícil diversificar el interés bibliográfico cuando se carece de poder adquisitivo ${ }^{49}$. En el caso del marqués del Cenete no tenemos duda de su poder adquisitivo, pero sí genera incógnitas sobre su interés literario la ingente cantidad de obras de su

48. Sánchez Cantón 1942, p. 36; y Romero Medina 2018, p. 736.

49. Pedraza Gracia 1999, pp. 144-145. 
colección sin seguir un patrón definido de temáticas y unas autorías específicas que permitan entrever las inquietudes culturales de Rodrigo de Mendoza.

En este sentido, Víctor Infantes ${ }^{50}$ estableció al respecto una clasificación de las bibliotecas cuya caracterización se encuentra en el número de libros que las componen y que nos servirá para determinar qué tipo de biblioteca poseía el marqués:

- Una biblioteca práctica es aquella que no posee más de 10 o 15 títulos en la que [...] el libro aparece como un bien primario y elemental [...] se trata de libros (sólo) para ser leídos [...].

- La biblioteca profesional es la que está constituida por más de 10 o 15 títulos y menos de 50 o 60 y en la que el libro [...] tiene una función eminentemente de consulta y manejo vinculada al aprendizaje o al ejercicio de (determinada) actividad [...].

- La biblioteca patrimonial es la colección bibliográfica que alcanzaría hasta los 300 títulos y en ella [...] el libro adquiere la (con)notación de bien suntuario [...] en donde se puede analizar la formación de la biblioteca por herencia(s), por las posibilidades de adquisición del propietario o por un afán coleccionista $[\ldots]$.

- Una biblioteca museo es la que está compuesta por un número de libros superior a los 300 y en la cual [...] el libro representa un exponente de riqueza $[\ldots]$ en correspondencia con una serie de bienes que integran a los libros en un testimonio de posesión y de lujo [...].

En este sentido, aunque la colección del marqués, obviamente, se encuadra en la definición de una biblioteca museo, puesto que tal cantidad de obras no hacen más que indicar un carácter más bien coleccionista que no lector, sí es cierto que, dentro de esa catalogación apresurada de sus bienes bibliográficos, podríamos encontrar ejemplos de lo que serían, según la comentada clasificación, las bibliotecas prácticas, profesionales y patrimoniales. Consideramos que, aunque los 653 volúmenes de su repertorio indican ese afán coleccionista que le era innato al marqués y que tenía por objetivo, seguramente, hacer ostentación de su poder adquisitivo y elevada posición, no deja de ser bastante probable que algunos de ellos, por ejemplo, los que se hallaban junto a él en el momento de su fallecimiento (generalmente, de una variedad temática que muestra un gusto interdisciplinar, quizá haciendo hincapié en ciertos autores de su más que probable interés personal en los últimos años de su existencia, como Ptolomeo, Eiximenis, Volterra, Galeno, Dante, Petrarca, etc.), fueran de su constante consulta y lectura, mientras que otros, como algunos de medicina y derecho (los cuales, como ya hemos visto, son abundantes) le sirvieran al aristócrata de fuente para su formación en ciertos ámbitos de su interés o curiosidad y, por tanto, se enmarcarían en el concepto de biblioteca profesional. Y, por último, el resto de obras, verbigracia, aquellas de las que sólo poseyó un ejemplar y que, en principio, revelan un interés menor que

50. Infantes 1997, pp. 287-288; Pedraza Gracia 1999, pp. 26-28. 


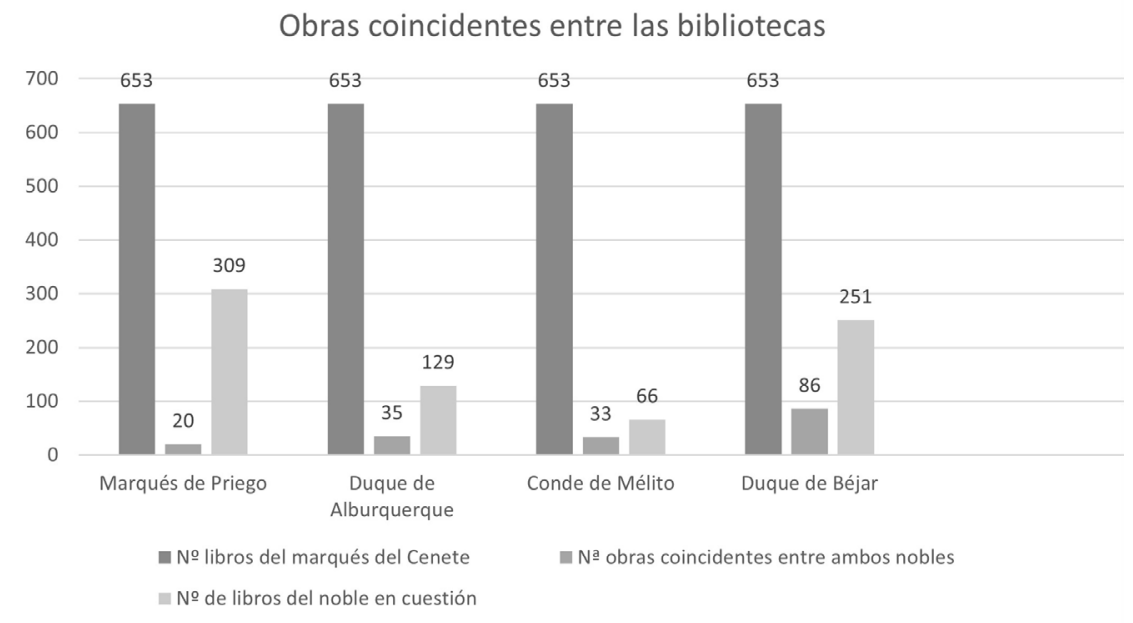

Gráfico 4. Obras coincidentes entre las bibliotecas más reseñables.

otras de las que atesoró diferentes ediciones, que encarnarían el ideario coleccionista de Rodrigo de Mendoza.

A modo comparativo para poder entender nuestra teoría alejada de la presunción de un perfil meramente coleccionista del aristócrata, y sobre todo en relación con otras bibliotecas nobiliarias castellanas y coetáneas a la suya, observamos lo siguiente:

- En primer lugar, la diferencia abismal entre las diversas colecciones (hemos optado por centrarnos en aquellas bibliotecas de las que hemos hallado estudio de su inventario ${ }^{51}$ y de las que hemos podido realizar una comparación veraz entre las obras poseídas) con respecto a la cantidad de volúmenes que poseyó el marqués. Dudamos que cualquier otro noble de la época (incluso anterior y posterior a él, con la excepción de su hija Mencía) llegara a poseer tal rica, variada e ingente colección. Algo al alcance de la realeza, seguramente.

- En segundo lugar, es cierto que el aristócrata conservó sus libros en cajas, como ya hemos comentado anteriormente y sobre lo que ya hemos aportado nuestra hipótesis, pero si seguimos el patrón de que, por estar en cajas, era síntoma de desinterés del propietario ${ }^{52}$, ¿por qué, entonces, no encontramos todo tipo de autorías y de temáticas (caballerescas, amorosas, etc.)

51. Redondo 1967,p. 193; Quintanilla Raso 1980, pp. 347-353; Dadson 1993, pp. 400-432; Ruiz García y Carceller Cerviño 2002, pp. 361-372.

52. Sánchez Cantón, F. J., La biblioteca..., op. cit., pp. 23 y ss.; Salgado Olmeda, F., "Humanismo y coleccionismo librario...", art. cit., p. 130. Pedraza Gracia, M. J., "Lector, lecturas, bibliotecas...", art. cit., p. 149, reitera la idea de que "El lugar donde se guardan los libros también es un elemento a tener muy en cuenta y, en este caso, no solamente la estancia o habitación donde se han encontrado los libros, sino también el lugar físico en el que se guardan [...]" y, en este sentido, 
que sí hallamos abundantemente en otros nobles? Es decir, si al marqués no le importaba la calidad sino la cantidad, ¿por qué su colección denota un interés por la erudición en su concepto más amplio y no coleccionar por coleccionar (y, con ello, podríamos haber hallado todo tipo de obras sin el más mínimo filtro riguroso ni culto que sí se denota en el inventario de sus bienes)? Si su único fin, a tenor de los conceptos generales que de este tipo de colecciones grandiosas se tiene, era la ostentación de una biblioteca, mejor dicho, de la mejor biblioteca privada del Reino de Valencia e, incluso, de toda la Corona de Aragón y del Reino de Castilla, podría haber atesorado todo tipo de libros siempre y cuando fueran acordes a su rango y ostentosidad. Pero, es sumamente llamativo que si el aristócrata no sentía interés alguno por la historia clásica y coetánea, la medicina, la geografía, la religión, la filosofía o la filología, ¿por qué este tipo de temática no es tan frecuente en otros nobles de su época y sólo coincide con ellos en un número irrisorio de volúmenes y no en la mayor parte de su colección, dado que, en el mejor de los casos, Rodrigo de Mendoza duplica la colección del aristócrata con más libros? Por lógica, si se tratara de una biblioteca no encaminada a su lectura y consulta (no en todos los casos, obviamente) y solamente al alarde, ¿por qué no vemos un mayor número de coincidencias entre bibliotecas? ¿No podría ser que la biblioteca Rodrigo fuera más personal, meditada, encaminada a poseer aquellas obras más acordes a sus intereses sin dejar de lado la más que posible función secundaria de mostrar su poder? Si todas las obras, temáticas, autorías, lenguas y ediciones tuvieran un nexo en común que fuera el hecho de hacer gala de la riqueza de cualquiera de los nobles analizados, el marqués tendría todas y cada una de las obras que poseyeron sus coetáneos y más teniendo en cuenta que superó los 600 ejemplares. Como ya hemos comentado con anterioridad, es posible que el cardenal Mendoza orientara dicha colección según sus gustos literarios, pero creemos, con toda seguridad, que su hijo la amplió en su mayor medida siguiendo las pautas de sus intereses intelectuales, no los que se repiten cual patrón (obras de carácter militar sobre todo, libros de novela amorosa y caballeresca, etc.) entre otras colecciones, como podemos observar en los estudios que se han realizado sobre las bibliotecas nobiliarias comparadas ${ }^{53}$, y que no se dan de manera tan sistemática en la colección del I conde del Cid; sino al contrario, nos da a entender la minuciosidad y el criterio que seguramente impuso Rodrigo de Mendoza con el fin de que su colección bibliográfica fuera perfilándose según sus particulares intereses y motivaciones.

- Por último, no quisiéramos concluir este análisis sin hacer mención a la poderosamente llamativa coincidencia de ejemplares entre el marqués del Cenete y su hermano Diego. Hay investigadores que recalcan la más que

determina que “[...] el abandono en una caja será indicio de una menor importancia del libro para quien lo posee $[\ldots]$ ".

53. Véase la nota 51 
probable transferencia de ciertos volúmenes entre la colección de Rodrigo y la del conde de Mélito a raíz del inventario post mortem que se realizó de los bienes del primero en presencia del segundo, en calidad de albacea y tutor de sus tres hijas ${ }^{54}$, pero ¿no resulta incomprensible cómo -si ambos hermanos fueron educados bajo los mismos preceptos y orientados a engrosar, de forma individual, el patrimonio iniciado por su padre-, la diferencia sea abismal entre ambas colecciones bibliográficas? Ambos tenían inquietudes militares que les llevaron a participar prácticamente en los mismos campos de batalla, tenían un patrimonio un tanto desigual por cuanto el cardenal Mendoza benefició sobremanera a su primogénito, y sus andaduras biográficas tuvieron un recorrido paralelo, aunque con fortuna dispar, ¿no demuestra este hecho de nuevo que la pasión del marqués por la lectura iba más allá del mero coleccionismo? Su hermano pudo seguir el mismo patrón y haber iniciado la adquisición de obras para la formación de una biblioteca que pudiera estar a la altura de su rango y poder, pero no fue así, y menos todavía si tenemos en cuenta que la mitad exacta de los volúmenes que poseyó coinciden a la perfección con los que tuvo su hermano; y es aquí cuando se nos plantea otra cuestión: ¿su ínfima colección libraria, en comparación con el resto de nobles comparados, se pudo conformar a raíz del fallecimiento de su hermano Rodrigo? Una vez más, ¿no es un claro índice de que el conde de Mélito no mostró una vocación hacia las letras, en cambio su hermano Rodrigo, a pesar de las apariencias, sí, y muestra de ello es su gran biblioteca repleta de unas temáticas concretas ya analizadas y de obras que podrían darnos la postrera pista de que las adquirió concienzudamente siguiendo exclusivamente el patrón de sus intereses?

Recogiendo este último testigo, nos centraremos en concreto en aquellos que podrían definir, por su elevada presencia en la citada colección, la afición lectora de Rodrigo de Mendoza.

Del total de obras, destaca especialmente la cantidad de libros no identificados o de identificación ambigua, es decir, aquellos registros que no hemos podido llegar a corroborar y encontrar una edición acorde al autor y/o título propuestos, pero también aquellos que sí hemos hallado en diferentes bibliotecas ediciones que pudieron corresponderse con la que poseyó el marqués pero que, por la propia ambigüedad generada por el notario a la hora de registrar la información de cada volumen que se fue sacando de las cajas, podría tratarse de diferentes autores que comparten un apellido o nombre parecido o incluso de diferentes obras compuestas por otra variedad de escritores que tienen en común el título y, además, comparten años de edición y tipo de soporte.

En este sentido, no nos debería extrañar la gran cantidad de autores de los que el marqués adquirió (o, en su defecto, heredó en parte) exclusivamente una obra (146 libros de la totalidad de la biblioteca): Lodovico Celio Rhodiginus ( $\left.\mathrm{n}^{\mathrm{o}} 15\right)$;

54. Dadson 1998, pp. 116-117 


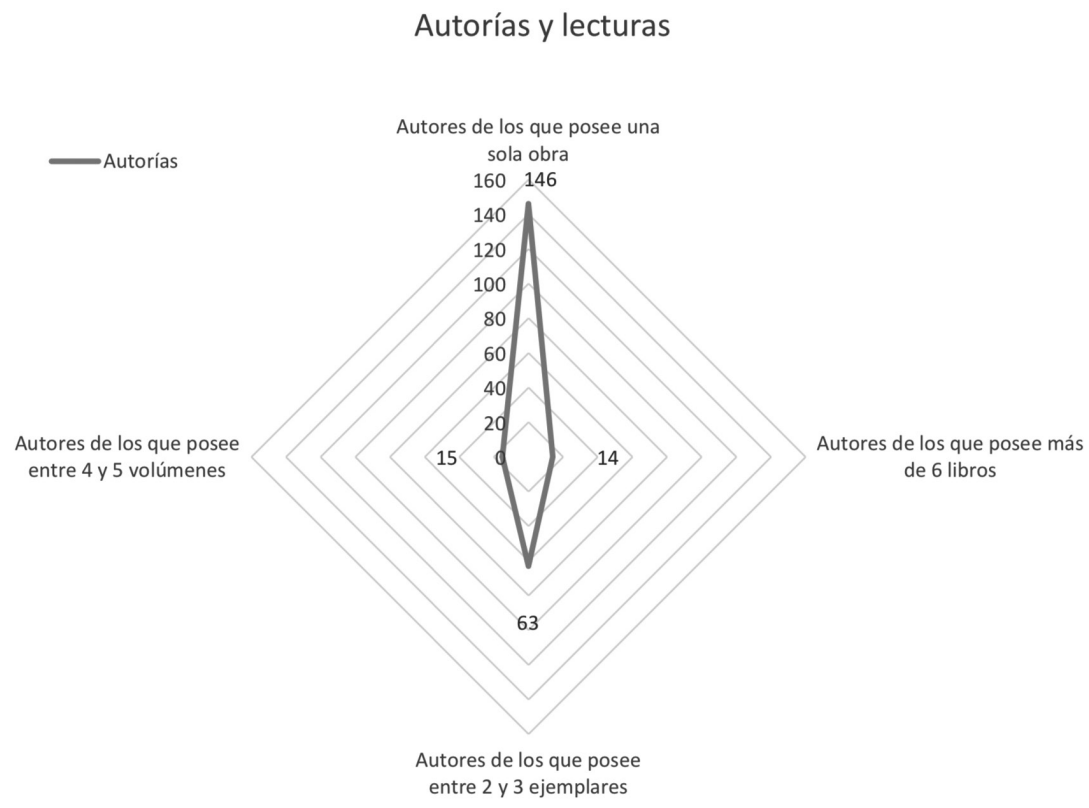

Gráfico 5. Autorías y lecturas.

Bartolomé Montagnana ( $\mathrm{n}^{\mathrm{o}}$ 16); Ottaviano Mirandola ( $\mathrm{n}^{\circ}$ 26); Walter Burley $\left(n^{\circ} 30\right)$; Marco Vigier ( $\left.n^{\circ} 62\right)$; Sorano Efesio ( $\left.n^{\circ} 68\right)$; Giovanni Arcolani (o Ercolani) de Verona ( $\left.\mathrm{n}^{\circ} 70\right)$; Baverio de Baveria ( $\left.\mathrm{n}^{\circ} 71\right)$; Ugo Benzio da Siena $\left(\mathrm{n}^{\circ}\right.$ 72); Pietro de Argellata ( $\left.n^{\circ} 75\right)$; Johannes de Gaddesden ( $\left.n^{\circ} 77\right)$; Guy de Chauliac $\left(n^{\circ} 78\right)$; Herculano de Peruggia ( $\left.n^{\circ} 79\right)$; Paulo Suardo $\left(n^{\circ} 80\right)$; Marsilio de Inghen $\left(n^{\circ} 85\right)$; Cristoforo da Barzizza ( $\left.{ }^{\circ} 86\right)$; Alfonso de Córdoba ( $\left.n^{\circ} 95\right)$; Giacomo Manlio de Bosco ( $\mathrm{n}^{\circ}$ 102); Paulo de Egina ( ${ }^{\circ}$ 107); Thomas Rudinus Thodischus ( $\left.n^{\circ} 109\right)$; Nicolás Bertrucci ( $\left.n^{\circ} 110\right)$; Gilbertus Anglicus ( $\left.n^{\circ} 111\right)$; Hermes Trismegisto ( $\left.\mathrm{n}^{\circ} 117\right)$; San Juan Damasceno $\left(\mathrm{n}^{\circ} 119\right)$; Heinrich Institoris y Jakob Sprenger ( $\left.\mathrm{n}^{\circ} 124\right)$; Thomas Bricot ( $\left.\mathrm{n}^{\circ} 127\right)$; Antonio Rampegollo ( $\left.\mathrm{n}^{\circ} 128\right)$; Robert Holkot ( $\left.n^{\circ} 129\right)$; pseudo San Alberto Magno ( $\left.{ }^{\circ} 130\right)$; pseudo San Buenaventura $\left(n^{\circ} 133\right)$; Tiberio Cacio Asconio Silio Itálico ( $\left.n^{\circ} 141\right)$; Giovanni Joviano Pontano $\left(n^{\circ} 143\right)$; Jenofonte ( $\left.n^{\circ} 146\right)$; Eurípides ( $\left.n^{\circ} 157\right)$; Hipócrates $\left(n^{\circ} 162\right)$; Serafino Aquilano ( $\mathrm{n}^{\mathrm{o}}$ 165); Marco Antonio Coccio Sabellico ( $\left.\mathrm{n}^{\circ} 167\right)$; Alonso de Espina $\left(\mathrm{n}^{\circ}\right.$ 170); Aulo Persio Flaco ( $\left.\mathrm{n}^{\circ} 181\right)$; Ægidius Corboliensis $\left(\mathrm{n}^{\circ} 184\right)$; Simphorianus Champerius ( $\mathrm{n}^{\circ}$ 188); Marco Gattinara de Verceli ( $\left.\mathrm{n}^{\circ} 192\right)$; Herodiano $\left(\mathrm{n}^{\circ}\right.$ 195); Quinto Septimio Florente Tertuliano ( $\left.\mathrm{n}^{\circ} 196\right)$; Bernhard von Breydenbach $\left(n^{\circ} 211\right)$; Fernando Díaz de Toledo ( $\left.n^{\circ} 213\right)$; Juan de Ortega ( $\left.n^{\circ} 214\right)$; Antonio da Pistoia ( $\left.n^{\circ} 216\right)$; Lope Obregón ( $\left.n^{\circ} 217\right)$; Ricoldo da Montecroce ( $\left.n^{\circ} 218\right)$; Juan Andrés Zaragoza ( $\left.n^{\circ} 219\right)$; Íñigo López de Mendoza ( $\left.n^{\circ} 220\right)$; Claudio Claudiano $\left(n^{\circ} 221\right)$; Pierre Bertrand ( $\left.n^{\circ} 222\right)$; Pedro de Alcalá ( $\left.n^{\circ} 223\right)$; pseudo Catón $\left(n^{\circ}\right.$ 224); Fernando Mejía (nº 228); Diego de Muros (n 233); Tomás de Perpenyà (no 
234); Verner Rolevinck ( $\left.n^{\circ} 238\right)$; Gaspare Lampugnani ( $\left.n^{\circ} 242\right)$; Johannes Scotus Erigena ( $\mathrm{n}^{\circ}$ 257); Dionisio Areopagita ( $\left.\mathrm{n}^{\circ} 258\right)$; Ricardo de Mediavilla ( $\left.\mathrm{n}^{\circ} 273\right)$; Juan Duns Scoto ( $\left.\mathrm{n}^{\circ} 274\right)$; Luciano de Samosata ( $\left.\mathrm{n}^{\circ} 278\right)$; Cayo Plinio Cecilio $\left(n^{\circ} 279\right)$; Michele Riccio ( ${ }^{\circ}$ 291); Tucídides ( $\left.n^{\circ} 292\right)$; Hugo de Prato Florido ( $n^{\circ}$ 204); Graciano ( $\mathrm{n}^{\circ}$ 296); Cayo Suetonio Tranquilo ( $\left.\mathrm{n}^{\circ} 301\right)$; Ambrosio Aurelio Teodosio Macrobio ( $\left.{ }^{\circ} 302\right)$; Giacomo Filippo de Bergamo $\left(n^{\circ} 305\right)$; Maurilianus Pamphilius ( $n^{\circ} 308$ ); Estrabón ( ${ }^{\circ}$ 405); Lucio Marineo Sículo ( $n^{\circ} 316$ ); Marco Fabio Quintiliano ( $\left.\mathrm{n}^{\circ} 317\right)$; Lorenzo Valla ( $\mathrm{n}^{\circ} 318$ ); Diodoro Sículo ( $\left.\mathrm{n}^{\mathrm{o}} 319\right)$; Albrecht von Eyb ( $\left.n^{\circ} 320\right)$; Pietro Crinito ( $\left.n^{\circ} 326\right)$; San Isidoro de Sevilla ( $\left.n^{\circ} 329\right)$; Tito Lucrecio Caro ( $\left.n^{\circ} 337\right)$; pseudo Phalaris ( $\left.n^{\circ} 338\right)$; Polidoro Virgilio ( $\left.n^{\circ} 339\right)$; Aulo Gelio ( $\left.\mathrm{n}^{\mathrm{o}} 341\right)$; Agostino Dati ( $\left.\mathrm{n}^{\circ} 342\right)$; Desiderio Erasmo ( $\left.{ }^{\circ} 344\right)$; Prisciano Cesariense ( $\left.\mathrm{n}^{\mathrm{o}} 345\right)$; Johannes Balbus ( $\left.\mathrm{n}^{\circ} 350\right)$; Cayo Valerio Catulo, Sexto Aurelio Propercio y Albio Tibulo ( $n^{\circ} 356$ ); Luca Pacioli ( $\left.n^{\circ} 357\right)$; Sexto Pompeyo Festo ( $\mathrm{n}^{\circ} 359$ ); Johannes Antonius Campanus ( $\left.\mathrm{n}^{\circ} 360\right)$; Urbano Bolzanio $\left(n^{\circ} 364\right)$; Leon Battista Alberti ( $\left.n^{\circ} 374\right)$; Dionysius Nestor ( $\left.{ }^{\circ} 375\right)$; Papias $\left(n^{\circ}\right.$ 376); Ali Ibn Al-Abbas Al-Magusi ( $n^{\circ} 388$ ); Pietro Bembo ( $\left.n^{\circ} 396\right)$; Lucio Celio Firmiano Lactancio ( ${ }^{\circ}$ 404); Marco Vitruvio Polión ( $\left.n^{\circ} 408\right)$; Aloise Cinzio delli Fabrizi ( $\left.n^{\circ} 413\right)$; Ægidus Aurifaber ( $\left.n^{\circ} 418\right)$; Giovanni Francesco Bracciolini $\left(n^{\circ}\right.$ 424); Paulo Orosio ( $\left.n^{\circ} 432\right)$; Gregor Reisch ( $\left.n^{\circ} 433\right)$; Juan López de Ayora $\left(n^{\circ}\right.$ 435); Antonio Tibaldeo ( $\left.n^{\circ} 438\right)$; Guido Bonatti ( $\left.n^{\circ} 456\right)$; Jean de Jandun $\left(n^{\circ} 458\right)$; Ægidius Romanus ( $\left.\mathrm{n}^{\circ} 467\right)$; Lambertus de Monte Domini ( $\left.\mathrm{n}^{\circ} 468\right)$; Mondino dei Luzzi ( ${ }^{\circ}$ 471); pseudo Aristóteles ( $n^{\circ} 472$ ); Nicolaus Bonetus ( ${ }^{\circ} 483$ ); Antonio Trombetta ( ${ }^{\circ}$ 493); Juan Pedro Julián ( $\left.n^{\circ} 498\right)$; Ramón de Penyafort y Adam Alderspacensis ( $n^{\circ}$ 502); Abū-Ma '̌́ar Ğa 'Far Ibn-Muhammad (nº 504); Giovanni Matheo Ferrari de Gradi ( $\left.n^{\circ} 505\right)$; Girolamo Balbi ( $\left.n^{\circ} 506\right)$; Dioscórides ( $\left.n^{\circ} 507\right)$; Antonio Guainerio ( $\left.n^{\circ} 510\right)$; Panteleón de Conflenza ( $\left.n^{\circ} 514\right)$; Petrus de Abano ( $n^{\circ}$ 527); Johannes Sermoneta ( $\left.n^{\circ} 539\right)$; Johannes de Ketham ( $\left.n^{\circ} 540\right)$; Petrus Turrisanus ( $\left.n^{\circ} 543\right)$; Giovanni de Vigo ( $\left.n^{\circ} 544\right)$; Francesco Filelfo ( $\left.n^{\circ} 545\right)$; Guillaume Durand ( $\left.n^{\circ} 565\right)$; Julio Firmico Materno ( $\left.n^{\circ} 566\right)$; Platón ( $\left.n^{\circ} 570\right)$; Plotino ( $\left.n^{\circ} 571\right)$; Diógenes Laercio ( $\mathrm{n}^{\circ} 572$ ); pseudo Séneca ( $\left.\mathrm{n}^{\circ} 575\right)$; Quinto Curcio Rufo ( $\left.\mathrm{n}^{\circ} 581\right)$; beato Jacopo della Voragine ( $\left.n^{\circ} 584\right)$; Diego Rodríguez de Almela ( $\left.n^{\circ} 596\right)$; Juan del Encina ( $\left.{ }^{\circ} 603\right)$; Feliciano de Silva ( $\left.n^{\circ} 605\right)$; Pedro del Corral ( $\left.n^{\circ} 612\right)$; Gabriel Alonso de Herrera ( $\left.n^{\circ} 617\right)$; Giacopo Caviceo ( $\left.{ }^{\circ} 619\right)$; y Julián Gutiérrez ( $\left.n^{\circ} 621\right)$.

¿Puede ser casualidad que algunos escritores sólo tuvieran una obra relevante y que el aristócrata no dudara en incluirla en su colección, o podría tratarse de una decisión premeditada y poseyera el volumen que le interesaba del autor en cuestión? ¿O, por el contrario, es un indicador de que no eran autores, obras o temáticas que estimularan el espíritu lector del propietario, pero sí era consciente, quizá, de su valor y de lo que implicaría tener dicho volumen entre sus adquisiciones? Es difícil de determinar, puesto que aquí también entraría en liza hasta qué punto esos libros fueron adquiridos por el cardenal y, en consecuencia, al legárselos, fueran o no del gusto y de la lectura de Rodrigo de Mendoza. Por lo que respecta a este grupo de libros, tan disperso y variado, no podemos extraer información de relevancia, puesto que la posesión de un único ejemplar tampoco nos ofrece suficiente 
información como para llegar a realizar hipótesis con fundamento o trazar posibles conclusiones, entre otros motivos, porque esto retroalimentaría la hipótesis de que esta biblioteca tenía un carácter más coleccionista que erudita, ya que se dan todo tipo de autores, ediciones, obras y temáticas sin un nexo claro. ¿Es posible que las obras de Vitruvio y Alberti las adquiriera a conciencia puesto que su interés por la arquitectura era más que evidente? Sí, es más que probable, pero al no mostrar el mismo patrón que en otras obras que se repiten en muchas ocasiones y traslucen, en un principio, un mayor interés del marqués del Cenete, no podemos extraer conclusiones plausibles.

Lo que, a nuestro parecer, sí resulta relevante y sumamente interesante son todos aquellos autores que se repiten en más de dos ocasiones en dicha colección. Empezaremos por aquellas autorías cuyas obras vemos ejemplificadas en la biblioteca Rodrigo de Mendoza entre dos y tres veces (63 obras): Hernando del Castillo ( $\left.n^{\circ} 27,229,574\right)$; Antonio Gazius ( ${ }^{\circ} 28$ y 87); Marsilio Ficino (n 31 y 115); Aulo Cornelio Celso ( ${ }^{\circ} 59$ y 168); Guillaume Budé ( ${ }^{\circ} 60$ y 511); Giovanni Pico della Mirandola ( $n^{\circ} 61$ y 262); Simón de Génova o Januensis ( $n^{\circ} 64$ y 65); Antonio Cermisoni ( $n^{\circ} 74$ y 76); Hiaya ben Isaac ( $n^{\circ} 84$ y 513$)$; Thomasso di Dino del Garbo ( $n^{\circ} 88$ y 532); Cayo Julio Hygino ( ${ }^{\circ} 91$ y 98); Gabriel Biel ( ${ }^{\circ} 97,254$ y 259); Agostino Ricchi ( $n^{\circ} 106$ y 163); Bartholomaeus Sacchi Platine ( $n^{\circ} 114,154$ y 471); Martinus Polonus ( ${ }^{\circ} 122,161$ y 166); Antonino di Perozzo ( $n^{\circ} 126$ y 541); Decio Junio Juvenal ( ${ }^{\circ} 132$ y 330); Marco Juniano Justino ( $n^{\circ} 158,299$ y 340); Publio Terencio Africano ( ${ }^{\circ} 173$ y 362); Niccolò Perotto ( ${ }^{\circ}$ 207, 348 y 349); Jehan Bagnyon ( $n^{\circ} 209$ y 602); Diego de Valera (nº 227 y 410); Franchino Gaffurio $\left(n^{\circ} 230,231\right.$ y 509); Juan de Mena (n 239 y 597); San Agustín (n 244 y 252); San Buenaventura ( $\mathrm{n}^{\circ} 248$ y 249); Joannes Major ( $\mathrm{n}^{\circ} 251,261$ y 276); Santo Tomás de Aquino ( ${ }^{\circ} 255,461$ y 512); William of Ockham ( $n^{\circ} 260$ y 275); Cayo Plinio Cecilio ( ${ }^{\circ} 279$ y 402); Pietro del Monte (n 300, 351 y 373); Homero (n⿳ 303 y 423); Lucio Junio Moderato Columela ( $n^{\circ} 310,397$ y 537); Enea Silvio Piccolomini ( ${ }^{\circ}$ 332 y 398); Sexto Aurelio Propercio (nº 335 y 356); Giorgio Valla ( $n^{\circ} 336$ y 449); Ambrogio Calepino ( $n^{\circ} 346$ y 347); Publio Virgilio Marón ( $n^{\circ} 354$ y 355); Lucio Apuleyo ( $n^{\circ} 365$ y 601); Flavio Josefo ( $n^{\circ} 377$ y 419); Rolandinus de Passageriis $\left(n^{\circ} 400,401\right.$ y 412); Giacomo Filippo Foresti ( $n^{\circ} 411$ y 583); Giovanni Boccaccio $\left(n^{\circ} 427\right.$ y 586); Flavio Renato Vegecio ( $n^{\circ} 430$ y 501); Alfonso de Madrigal ( ${ }^{\circ} 436$ y 607); Abraham Zacuto (ño 446 y 447); 'Alī Abū al-Hasan al-šaybān̄̄ Ibn Ab̄̄ AlRiğāl ( $n^{\circ} 450$ y 452); Johannes de Sacro Bosco (nº 454 y 455); Jacques Le Fèvre d'Etaples (nº 473 y 508); Gaspar Lax (n 477, 480 y 486); Ramon Llull (nº 497 y 499); Johannes Michæl Savonarola (nº 530, 531 y 559); San Juan Crisóstomo (n 546,547 y 553); Leonardo Bruni ( $\mathrm{n}^{\mathrm{o}} 556,557$ y 558); y Lodolphus de Saxonia ( ${ }^{\circ}$ $576,577$ y 578$)$.

¿Son obras que, por fortuna, se han visto duplicadas o triplicadas en la colección o se tratan de obras compradas a propósito por su valor material, por su calidad o por el interés que les suscitaría a Rodrigo de Mendoza? ¿O, por todo lo contrario, se adquirirían sin reparar que ya las tenía? ¿Podemos determinar hasta qué punto todas estas obras tenían una función práctica, formativa, profesional o 
simple y llanamente coleccionista? Resulta harto complejo, pero la diferencia entre aquellas obras de las que sólo poseyó un ejemplar (cuya motivación es difícil de especificar) y aquellas de las que empezamos a comprobar que su presencia en la colección va in crescendo, nos demuestra cómo se van perfilando los intereses de nuestro personaje, aunque de momento sigamos contemplando una gran variedad de temáticas, obras y autores que no permiten del todo poder analizar ese gusto literario más allá del mero hecho de una mayor presencia de los autores concretos que hemos especificado.

A continuación, destacaremos aquellos escritores cuyas obras aparecen entre tres y cinco ocasiones registradas en el inventario (con un total de 15 entradas): Claudio Galeno ( $\mathrm{n}^{\mathrm{o}} 1,69,189,190$ y 393); Ugo Benzio da Siena $\left(\mathrm{n}^{\circ} 72,516,524\right.$ y 525); Tito Maccio Plauto ( $\mathrm{n}^{\circ} 135,150,185$ y 363); Marco Anneo Lucano ( ${ }^{\circ} 136$, 180, 311 y 459); Juan Bautista de Mantua (n $160,169,567,568$ y 569); Pedro Lombardo ( $\mathrm{n}^{\circ}$ 176, 245, 246, 247 y 250); Cayo Salustio Crispo (no 177, 205, 331 y 425); Anicio Manlio Torcuato Severino Boecio ( $\mathrm{n}^{\circ} 194,560,561$ y 587); Valerio Máximo (nº 202, 352, 536 y 599); Lucio Anneo Séneca (nº 203, 428, 589 y 595); Elio Antonio de Nebrija ( ${ }^{\circ} 235,367,368,414$ y 434); Nicolò Falcucci (n ${ }^{\circ} 389$, 390, 391, 392 y 395); Jean Buridan ( $\mathrm{n}^{\circ}$ 485; 490; 491 y 496); Jean Buridan ( ${ }^{\circ}$ 485, 490, 491 y 496); Jacopo da Forli ( ${ }^{\circ} 517,521,522$ y 523); y Giasone del Maino ( ${ }^{\circ} 562,563,564$ y 564 bis).

Aquí ya podemos trazar con mayor seguridad un patrón en la personalidad del noble que sanciona sus intereses intelectuales y que se verá culminado en el siguiente grupo de libros a estudiar, puesto que el hecho de que destaquen 16 autores cuyas obras podemos encontrar entre tres y cuatro ocasiones en la colección llama poderosamente nuestra atención por lo que implica no sólo el hecho de su frecuente presencia en la biblioteca sino porque es un claro indicio de aquello que sería de mayor interés para Mendoza. ¿Podrían ser todos ejemplares adquiridos por el marqués y, casualmente, se repiten en la colección, pero no guardan relación con sus posibles intereses? Podría ser, pero es cierto que hay ediciones que se enmarcan en el contexto del cardenal Mendoza y que, en consecuencia, cuentan con más posibilidades de haber sido compradas por él con el fin de iniciar la colección bibliográfica de su primogénito, pero hemos demostrado que no todas las obras pudieron haber tenido el mismo recorrido histórico, de hecho ¿qué sospechas tenemos para descartar que el marqués del Cenete pudiera adquirir motu proprio ediciones anteriores a la muerte de su progenitor? Otra posibilidad que subyace a este análisis es la probable adquisición de ciertas obras por parte de González de Mendoza que hubieran calado en la formación del marqués y hubieran influido en sus intereses literarios, condicionando sus futuras compras con el fin de poseer otras ediciones, otros títulos de los mismos autores o, incluso, diferentes interpretaciones que otros eruditos realizaran de las obras en cuestión y que no dejarían de demostrar el interés de Rodrigo de Mendoza por abarcar el máximo conocimiento posible de dicho tema, obra o autoría. Es más, a través de esta primera criba a tener en mayor consideración, se pueden determinar con más consistencia las temáticas por la que se sentiría más atraído: la medicina (de la mano de Galeno, Jacopo da Forli y 
de Nicolò Falcucci), la filológica-erudita-literaria (Plauto, Lucano, Marcial, Juan Bautista de Mantua, Nebrija), la filosófica (Boecio, Jean Buridan y Paolo Veneto), la histórica (Salustio y Valerio Máximo), la científica natural (Plinio el Viejo), la del derecho (Giasone del Maino) y la religiosa (Pedro Lombardo). Autores que secundan nuestra hipótesis de que no solo era un acérrimo seguidor de sus obras, sino también que el del Cenete era totalmente consciente de qué autores leía: los más significativos y redundantes en época medieval, escritores clave en sus diferentes disciplinas, máximos exponentes de cada área temática (sin olvidar, claro está, la presencia de otros autores representativos, citados en los anteriores grupos de obras estudiados, de dichas índoles pero no tan representativa como los mencionados).

Por último, y más interesante en nuestra opinión es la cuantiosa representación que ciertos escritores en concreto tienen en la biblioteca del marqués con más de seis volúmenes (14 en total: Dante Alighieri $\left(\mathrm{n}^{\circ} 24,56,152,225,236,582\right.$ y 613 ); Francesco Petrarca (n ${ }^{\circ} 25,58,204,232,237,327,588,598,614,615,616$ y 618); Publio Ovidio Nasón (nº 81, 120, 174, 197, 199, 201, 322, 323, 324, 366, 370, 371 y 585); Tito Livio ( $\mathrm{n}^{\mathrm{o}} 118,134,147,297,403$ y 580); Cayo Julio César ( ${ }^{\circ}$ 125, 137, 144, 200, 416 y 429); Muḥammad ibn Zakarīyā Abū Bakr al-Rāzī (nº 131, 138, 382, 383, 519 y 538); Marco Tulio Cicerón ( $n^{\circ} 142,172,175,193,198,243$, 304, 306, 307, 358 y 426); Quinto Horacio Flaco (nº 151, 312, 313, 314, 315, 361 y 372); Aristóteles ( $n^{\circ} 178,179,283,284,464,465,489,518$ y 591); San Alberto Magno ( $n^{\circ} 263,264,265,460,474$ y 482); Orígenes (nº 266, 267, 268, 269, 554 y 555); San Jerónimo ( $\mathrm{n}^{\mathrm{o}} 272,548,549,549$ bis, 549 bisbis, 550 y 611); Avicena ( $\mathrm{n}^{\circ}$ $378,379,380,381,381$ bis, 384, 385, 386, 387, 388, 479, 503, 515 y 520); y Paolo Veneto ( $\mathrm{n}^{\mathrm{o}} 451,475,478,484,492$ y 494), puesto que si, a medida que hemos ido analizando por secciones y representaciones en la biblioteca de diferentes obras y, por ende, hemos podido ir esbozando el gusto literario de Rodrigo de Mendoza, ahora podemos $-\mathrm{y}$ debemos- exponer definitivamente nuestra teoría. A simple vista, podemos observar dos grupos claramente distinguibles: los autores clásicos de referencia (Ovidio, Tito Livio, César, Cicerón, Horacio, Aristóteles y Orígenes, aunque este último no es clásico sino cristiano) y los autores medievales y/o humanistas (Avicena, Al-Razi, San Alberto Magno, Dante y Petrarca). No es más que un ejemplo del binomio clásico-medieval que hallamos en otras bibliotecas predestinadas a ser catalogadas como humanistas. Además, independientemente de la presencia de los humanistas italianos también presentes en prácticamente todas las bibliotecas nobiliarias analizadas en comparación a la de nuestro protagonista, ¿no es evidente el clarísimo interés del aristócrata por la historia de Roma contada a través de César y de Tito Livio, de la poesía de Ovidio y de Horacio, de la formación cristiana propuesta por Orígenes y San Alberto Magno y, por último, de los estudios médicos de Avicena y de Al-Razi? Si no tuviera un especial interés en poseer dichas obras y, además, diferentes ediciones de las mismas, ¿por qué no poseer sólo un ejemplar como en otros tantos casos y, en cambio, estos autores tienen un papel preponderante en la biblioteca? ¿Todos y cada uno de ellos serían exclusivamente herencia del cardenal Mendoza o quizá se deba a una razón más de fondo? Si el marqués aspiraba al ideal de humanista, ¿no sería lógico que 
tuviera todos los estudios u obras impresas del humanista por excelencia, es decir, de Petrarca? Y si, como proponemos, Rodrigo de Mendoza aspiraba a encarnar dichos ideales, ¿no sería lógico que su biblioteca fuera un claro ejemplo donde hallar todas aquellas obras que el propio Petrarca comenta a su hermano en una de sus epístolas ${ }^{55}$ como dignas de ser releídas y reestudiadas? Por otra parte, ¿cabría la posibilidad de que el aristócrata viera en la figura de los grandes de la historia de Roma como César el prototipo de hombre al que quería aspirar o, incluso, al que seguir sus pasos para hacer historia? ¿Por qué tanto interés por la historia de Roma a imitar si no es por el placer de leer y de saber del pasado o para encontrar un modelo de conducta? Pero, aun así, tampoco deja de sorprender la presencia de obras poéticas que nos indican, tal vez, una sensibilidad por este género que no cabría presuponer a un caballero como el citado, pero su marcada personalidad no exime su predisposición por el placer de leer clásicos, de saborear el modelo de poesía de la que no dejaron de nutrirse los poetas posteriores. Y, para concluir, tampoco es de extrañar el interés por la medicina de la mano de dos médicos árabes a cuál más modélico, sobre todo Avicena, a través del cual muchos otros tratados de medicina también hallados entre las obras de Rodrigo se compusieron basándose en sus preceptos.

No podemos más que corroborar que la formación de la colección bibliográfica de nuestro protagonista no fue compilada en vano ni exclusivamente con un fin decorativo, sino que fue formándose, seguramente a partir de los volúmenes recibidos tras la muerte de González de Mendoza, siguiendo los patrones humanistas que cabría suponer en la figura del marqués del Cenete obedeciendo, al fin y al cabo, a sus intereses, e hilvanando una imagen de sí mismo culta y formada, lectora y preparada, pero que sus complejas circunstancias vitales enturbiaron, conformándose un perfil psicológico abocado a la guerra y al conflicto tan alejados del humanista que procuraba encarnar. De hecho, ese espíritu lector del noble quedó reflejado a través de las palabras laudatorias que Joan Àngel González le dedicó en su Tragitriumpho ${ }^{56}$ :

\section{Era un Apolo en el arte de sus músicas y galas; en guerra amigo de Marte por real estandarte y en paz amigo de Palas. \\ César, en el perdonar; Pompeyo, en hazer honor; Trajano, en justificar; Marco Tullio en el hablar; Octavio en mostrar amor; $[\ldots]$}

55. Petrarca 1983, pp. 106-114.

56. Transcritas por Sánchez Cantón 1942, pp. 21-22. 
1.6. Los compradores de las obras en las almonedas celebradas entre 1529 y 1535

El objetivo principal del análisis de este último apartado no reside tanto en conocer todos los nombres (ya ofrecidos en cada entrada notarial que coincide con el registro de venta) como sí en valorar hasta qué punto pudo tener interés la biblioteca de Rodrigo de Mendoza entre sus contemporáneos cuando se subastó. Como ya hemos comentado con anterioridad a este capítulo, la posibilidad de que Mencía de Mendoza formara su colección bibliográfica partiendo de la de su padre es escasa, al menos a gran escala (aunque sí sería factible que de todos los ejemplares tomara para sí algunos que considerara de más valor sentimental), pero el interés que pudiera suscitar hacerse con la increíble variedad de ediciones e impresiones de su biblioteca tuvo un alcance considerable entre curiosos, coleccionistas, y, sobre todo, libreros.

De los 120 ejemplares vendidos a personas de toda índole, pero que sabemos a ciencia cierta a qué obras correspondieron gracias al estudio de Gómez-Ferrer ${ }^{57}$, llama poderosamente la atención que una importante cantidad (49 obras) recayera en las manos del librero Joan Tarragó (o Joan Baptista Tárrago ${ }^{58}$ ), quien fue el librero de cabecera de Mencía de Mendoza ${ }^{59}$, seguido a considerable distancia por Joan de Herrera (9 volúmenes) y Gaspar Ros (9 libros). Quizá la proximidad a la nueva marquesa del Cenete estimuló dicho interés por adquirir ciertas obras de su progenitor. El resto de compradores adquirieron no más de 3 ejemplares, siendo la mayoría poseedores de un solo libro de la colección del finado, hecho que nos da a entender que eran personas exclusivamente interesadas en las obras adquiridas.

Por otra parte, de todos ellos, sabemos a ciencia cierta que algunos eran libreros. Al ya mencionado Tarragó, habría que añadir a Galceran Dalmau, Joan de Herrera y a Reyner Barcelí (Bassali). Galceran Dalmau era valenciano (al igual que Herrera), hijo de un tejedor de velos ${ }^{60}$, en cambio, Reyner Barcelí era francés ${ }^{61}$. Asimismo, el bachiller Molina, ¿se referiría al bachiller Juan de Molina, autor de la edición de Los triumphos de Apiano de 1522? Sí que es cierto que en los registros de las almonedas se citan algunos detalles que podrían orientarnos hacia las profesiones de los compradores: a Joan Fabra, Joan Garcia, Joan Herrera, Andrés López, Joan Calbo, Lope Orujo, Joan Scuffer y a Pere Moreno se les denomina "mestres", por lo que, además de algunos de ellos, como ya se ha reseñado, fueran, además, libreros, también destacarían como profesionales en la enseñanza, sobre todo, Joan Calbo ${ }^{62}$ y Pere Moreno, de quienes se matiza ser maestros de arte y

57. 2010, pp. 231-246.

58. Berger 1987, p. 215

59. Así como nos especifica, basándose en el testimonio del marqués del Saltillo y en la documentación hallada en el archivo de la Casa de Palau referente a la familia del Cenete (legajos 118-157), Gil Fernández 2003, pp. 37-38, Mencía de Mendoza era "[...] cliente asidua de los libreros Juan de Tarragona [...], de Juan Enguerau, Juan Monardis, Antonio Sanahuia, Juan Garrán, y de los hermanos Antonio y Juan Cerdá [...], Pablo Borbón [...], Gregorio Boncio [...], Juan Mey [...]”.

60. Berger 1987, pp. 219 y 223.

61. Ibid., p. 215.

62. Febrer Romaguera 2003, p. 280. 


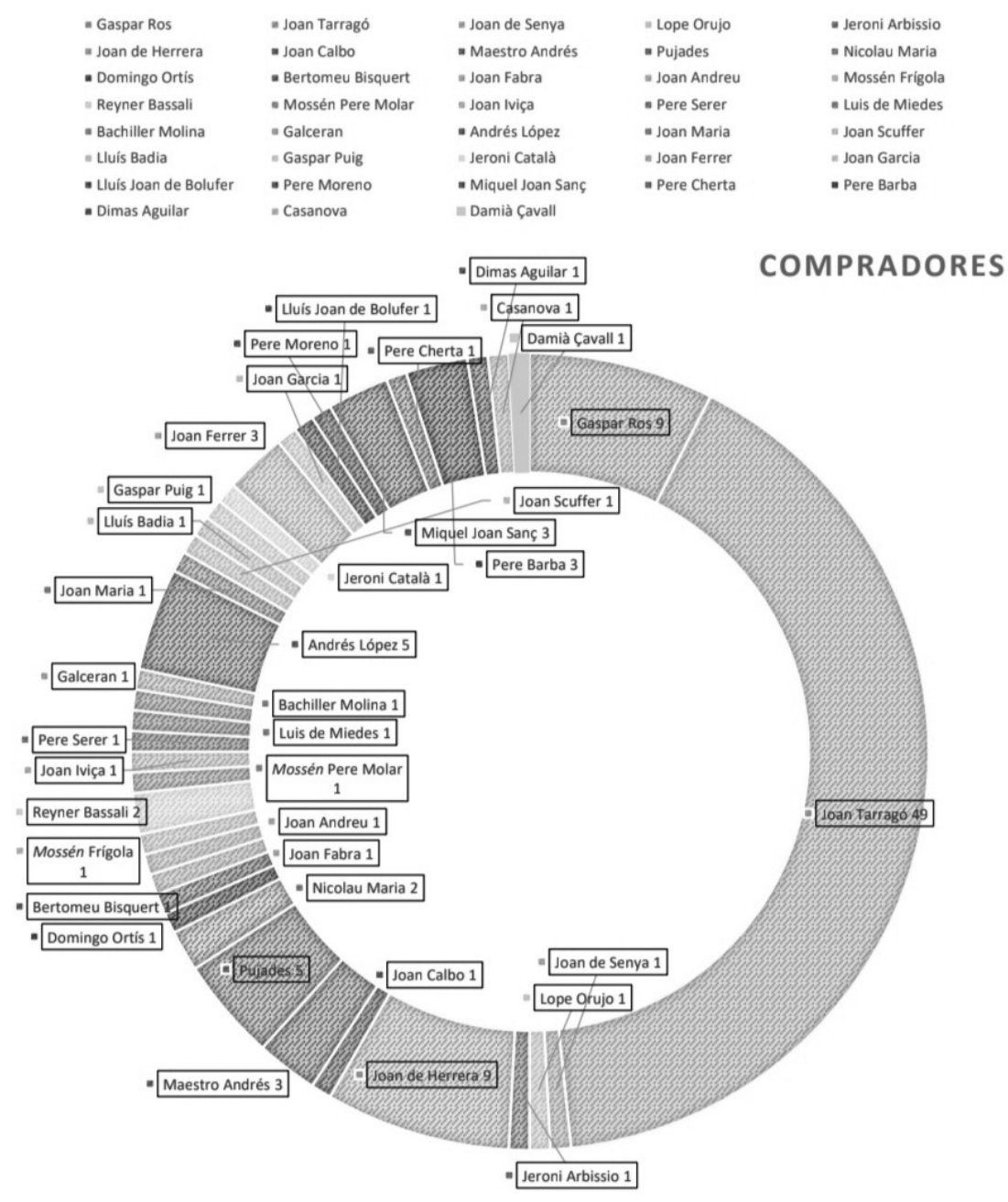

Gráfico 6. Los compradores.

medicina y de sacra teología, respectivamente. Y, aunque de Bertomeu Biquert no se menciona la especialidad de su maestría, ejerció de docente en artes en en Estudi General entre 1523 y $1524^{63}$. En relación a ello, también hemos hallado información sobre otros personajes como Luis Badia, quien fue un ciudadano valenciano propuesto para los oficios mayores de la ciudad en diversas ocasiones y con diferentes funciones entre 1513 y $1520^{64}$.

63. Ibid., p. 284.

64. Felipo Orts 2004, p. 180. 
Y, a pesar de que sólo en 120 ejemplares se menciona la autoría y la obra vendida, además del comprador en cuestión, hay 213 obras que se vendieron a la vez a Joan Baptista Bayarri (así como 3 libros de horas, que no se hallan en el inventario del marqués, a Guillem Taci, Lluís de Vich, Mestre Racional de la ciutat de Valencia, y al notario Marquo Dariera) pero que, quizá por el trabajo que hubiera supuesto referirlos uno por uno con cada volumen registrando título y/o autor, se optó por englobarlas como un lote vendido. ¿Cuáles serían? ¿Qué ocurrió con el resto de obras que no se vendieron o de los que no se tiene constancia documental de que se subastaran? ¿Los guardaría Mencía de Mendoza ampliando su colección hasta superar la de su padre? Aunque sabemos que Solervicens $\mathrm{Bo}^{65}$ está estudiando el inventario de las cajas de libros de la II marquesa del Cenete, sería alentador poder llegar a comparar ambas bibliotecas una vez identificada la primera, para poder determinar hasta qué punto sería posible un método similar a la que realizó Rodrigo de Mendoza con los ejemplares que, seguramente, recibió en herencia de su padre.

\section{Conclusiones}

Por lo que se refiere a la sensibilidad de Rodrigo de Mendoza para con el coleccionismo, particularmente libresco, ¿contamos con suficientes indicios que permitan situar la figura del noble dentro del ideal de humanista? Obviamente, ello dependería de la definición misma de 'humanista' que, por ejemplo, nos ofrece P. O. Kristeller ${ }^{66}$, entendiendo como tal al profesional de los studia humanitatis. En este sentido, obviamente el marqués del Cenete no lo sería, como tampoco otras tantas personalidades de su condición abocadas a otros menesteres. Pero de lo que no hay duda es de que sí sabía valorar la Antigüedad clásica como una época paradigmática, que sirvió como fuente para remodelar la vida de sus homólogos ${ }^{67}$; de hecho, la presencia mayoritaria de obras clásicas en la biblioteca con respecto a autorías y temáticas se debiera a ese afán por conocer de aquellos remotos antepasados y, quizá, impregnarse de su sabiduría. Esa idealización de la Antigüedad pareció no compartirla con la misma intensidad con otros nobles de la época y con algunos miembros de su familia, como, por ejemplo, el II conde de Tendilla, a pesar de sus respectivos vaivenes familiares y políticos, participar en los mismos conflictos (a excepción de la revuelta agermanada en el caso del granadino), tener contacto directo con las nuevas tendencias artísticas y literarias italianas gracias a sus viajes, y poseer excepcionales bibliotecas ${ }^{68}$.

La valoración de nuestro protagonista en ese sentido, por el contrario, cambia si se considera el concepto del habitus de una forma más amplia de humanista,

65. Solervicens Bo 2003, pp. 313-324.

66. Kristeller 1962, pp. 1-2.

67. Biersack 2018, p. 69.

68. Aunque en el caso del gobernador de Granada no hay información fehaciente de que los 650 ejemplares que se registraron en el inventario de 1580 fueran en su mayoría de su propiedad. 
mediante el cual se define como tal a toda persona formada en los studia humanitatis que adopta uno de sus rasgos específicos; es decir, que Rodrigo de Mendoza tal vez se consideraba a sí mismo imbuido de ese espíritu (y por ello ese interés añadido por la literatura procedente de Italia y el hecho de formar parte, seguramente, del círculo cultural y literario del conde de Oliva ${ }^{69}$ ).

Sus diversas estancias en Italia ${ }^{70}$ se sustanciaron además por su indudable interés por las artes, en su concepto más amplio, que quiso traer consigo para sus diversos proyectos arquitectónicos.

Ahora bien, la importancia de nuestro protagonista para poder entender la progresiva transferencia de la cultura humanista desde Italia a España radica sin duda en el nuevo ideal que alentaron los studia humanitatis, como se ha dicho. Y aunque es cierto que no destacó precisamente por la creación de obras literarias propias como sí realizaron otros miembros del linaje Mendoza, como su abuelo el marqués de Santillana, no cabe duda de que proporcionó una esmerada educación humanista a sus hijas, sobre todo a Mencía, y encarnando visiblemente en su persona el ideal de noble moldeado por la cultura renacentista.

Biersack $^{71}$, explica: La humanitas se convirtió en una distinción que igualaba al noble mecenas con el erudito, pero que lo separaba de un noble sin formación en las letras latinas $[. . .]^{72}$. Dudamos que el único objetivo de Rodrigo de Mendoza residiera en destacar a través de la erudición y formación con respecto a otros nobles, pero es probable que su cuantiosa biblioteca y afán coleccionista junto con sus actos, amistades e intereses culturales y personales estuvieran motivados por superar la reputación de otros aristócratas contemporáneos de su alcurnia.

Es posible que el interés del marqués del Cenete por el humanismo a raíz, sobre todo, de todos aquellos volúmenes que adquirió desde la muerte de su padre hasta su propio óbito, acrecentando, a la postre, su biblioteca hasta convertirla en una de las más sobresalientes, estuviera marcado por dos circunstancias: en primer lugar, porque una adecuada formación le hubiera proporcionado el conocimiento necesario para moverse con soltura en el mundo de la diplomacia (aunque no con la misma fortuna que su primogénita); en segundo y último lugar, para distinguirse, como ya hemos comentado, de nobles menos cultivados -como corolario, para relacionarse con la cúspide artística y literaria del momento en tierras italohispanas- y para superar en ostentación a linajes que, quizá, por su poder e influencia eran más importantes (un claro ejemplo lo encontramos al haber comparado su biblioteca con la de otros aristócratas), llegando a la conclusión de que su colección superaba con creces a cualquiera de las de sus contemporáneos independientemente de su rango y posición.

Al fin y al cabo, tanto las letras, en todas sus variedades, como la arquitectura y el arte renacentistas se convirtieron, junto con su controvertido carácter y su sucesiva participación en los conflictos acaecidos en Granada, Nápoles y

69. Ferragut y Ferrer del Río 2019, pp. 165-210.

70. Ferrer del Río y Ferrer Orts 2020, 297-319.

71. Basándose en Walther 2006, pp. 14-15.

72. Biersack 2018, p. 70. 
Valencia $^{73}$, en hitos que distinguieron sobremanera la vida de Rodrigo de Mendoza, convirtiéndose en signos inconfundibles tanto de su personalidad como también distintivos de su linaje, sólo acrecentados progresivamente por su sucesora, la II marquesa del Cenete, quien reforzó su estatus, prestigio e influencia merced a sus excepcionales colecciones, afán de conocimiento, diplomacia y matrimonios.

No cuestionamos que tan voluminosa colección bibliográfica fuera creada por el cardenal Mendoza (aunque no aparezca en su testamento referencia alguna), pero sí que fuera adquirida en exclusiva por él, siquiera en su mayoría. Que la finalidad de dicha colección fuera un símbolo de poder y estatus más allá de una función práctica (por cuanto la lectura de dichos ejemplares) es evidente, y más al ser comparada con otras bibliotecas contemporáneas con las que ni podía igualarse en número ni tampoco en variedad de autores y obras, puesto que el volumen de títulos coincidentes entre ellas $-\mathrm{y}$ que nos indicarían un gusto común o frecuente entre la aristocracia, principalmente castellana, de finales del siglo XV y principios del XVI- es irrisorio en su mayoría. Pero el hecho de que muchas primeras ediciones identificadas fueran posteriores al óbito de Pedro González de Mendoza es un claro indicador de que el marqués se encargó de adquirirlas ex professo.

Asimismo, tampoco tenemos la certeza de que las ediciones anteriores a 1495 hubiesen sido en su totalidad compradas por el mitrado, entre otros motivos, porque, como ya hemos indicado anteriormente, o bien existen otras ediciones posibles de la misma obra que también pudieron haberse correspondido con la poseída por Rodrigo de Mendoza o bien el noble castellano pudo haber adquirido con posterioridad a dicho año.

Por otra parte, exceptuando la información transmitida por el notario referente al título (y el idioma en el que está escrito), el autor y una breve -y en ocasiones escasa- descripción del volumen, no es seguro que dicha información sea verídica o incluso fruto de alguna equivocación teniendo en cuenta la ingente cantidad de bienes registrados. Prácticamente no tenemos la certeza del idioma, del tipo de encuadernación, incluso de la obra o del autor, motivo por el cual hemos realizado con cierta precaución el presente estudio, respetando lo registrado en la documentación original, pero siendo, en algunos casos, identificaciones hipotéticas.

Tampoco podemos certificar que nuestro protagonista supiera latín, italiano y/o catalán, pero proponemos esa posibilidad por cuanto no dudamos de la esmerada educación que seguramente recibiría, y por su contacto tanto con Italia como con el Reino de Valencia. Por otro lado, la información sobre la encuadernación nos da muestra en algunos registros de la exquisitez de ciertas ediciones y una probable explicación del porqué de su adquisición (por ende, de su valor).

Además, podemos asegurar que la división de temáticas de la biblioteca estudiada, a priori, no nos aporta luz sobre los gustos literarios del marqués, entre otras causas, por el hecho de que las obras, por ejemplo, de los Padres de la Iglesia (San Agustín, San Juan Crisóstomo, San Jerónimo, etc.) o de Avicena hubiesen sido, quizá, adquiridos por el cardenal Mendoza y no se hallaran, en consecuencia,

73. Remitimos a los estudios citados en la nota 2 . 
entre las lecturas preferidas de nuestro protagonista como, del mismo modo, aquellas de las que sí tenemos constancia de haber sido encargadas por el mismo (y, por ende, de su interés por poseerlas), pudieran mostrarnos una inclinación mayor con respecto, al menos, al humanismo italiano. Hecho que no niega que el mismo Rodrigo de Mendoza tuviera una particular afición por los autores clásicos latinos y se encargara de ir atesorando diferentes ediciones de Julio César o Cicerón, del mismo modo que tampoco podemos descartar que el marqués sí adquiriera obras sobre medicina, astronomía o filosofía. No podemos corroborar hasta qué punto nuestro protagonista compartiese gustos bibliófilos con su padre, o determinar cuáles eran sus preferencias lectoras, lo que sí es cierto es que tal cantidad de obras acumuladas contando con una biografía tan intensa es imposible que fuera siquiera consultada, por lo que el origen (que no la finalidad única) de dicha colección se fundamentaría, con toda probabilidad, en convertirse en un símbolo de ostentación y poder.

Por último, el hecho de conocer los compradores de dichos libros en las almonedas nos ha reportado noticias, especialmente de aquellos de los que existe información -y sobre los cuales han aportado luz algunos investigadores consultados y citados-, poder conocer, hasta cierta medida, su procedencia y, en concreto, su profesión, y así poder comprender qué motivación pudieron tener a la hora de comprar ciertos volúmenes. De todos ellos, destaca Joan Tarragó, no sólo fue quien adquirió más libros sino que ello estaría potencialmente motivado por su cercanía a la marquesa del Cenete -tal y como ya se ha explicado-. Quizá las exquisitas y valiosas ediciones que poseía el aristócrata fueron suficiente reclamo como para que algunos de los libreros de la capital del Turia acudieran a la subasta. Tal vez se tratase de particulares -sobre todo aquellos de los que no hemos encontrado dato alguno- que tuvieron un especial interés en títulos/autores concretos.

\section{BiBLIOGRAFÍA}

Berger, Philippe (1987), Libro y lectura en Valencia, Valencia.

Berger, Philippe (1989), "La decadence du valencien au XVIème siecle: le point de vue d'un temoin", Cahiers du CRIAR, 9, pp. 53-65.

Biersack, Martin (2018), "El II conde de Tendilla: cultura literaria y humanismo" en Bermúdez López, Jesús et alii (eds.), El conde de Tendilla y su tiempo, Granada, pp. 57-72.

Bouza Álvarez, Fernando (2000), ““F”. Cultura nobiliaria y ejercicios de guerra" en Hernando Sánchez, Carlos José (coord.), Las fortificaciones de Carlos V, Madrid, pp. 95-115.

Carpallo Bautista, Antonio (2002), “Análisis de un repertorio bibliográfico sobre la encuadernación española", Revista general de información y documentación, $12 / 2$, pp. 355-373.

Carpallo Bautista, Antonio (2009), "Estudio de las encuadernaciones del siglo XV de la Biblioteca Complutense”, Gutenberg-Jahrbuch, 2009, pp. 315-345. 
Dadson, Trevor J. (1993), "El mundo cultural de un Mendoza del Renacimiento: La biblioteca de Diego Hurtado de Mendoza, I conde de Mélito (1536)”, Boletín de la Real Academia Española, 73, pp. 383-432.

Dadson, Trevor J. (1998), Libros, lectores y lecturas, Madrid.

Falomir Faus, Miguel, Marías, Fernando (1994), "El primer viaje a Italia del marqués del Zenete", Anuario del Departamento de Historia y Teoría del Arte, 6 , pp. 101-120.

Febrer Romaguera, Manuel Vicente (2003), Ortodoxia y humanismo: el Estudio General de Valencia durante el rectorado de Joan de Salaya (1525-1558), Valencia.

Felipo Orts, Amparo (2004), Autoritarismo monárquico y reacción municipal: La oligarquía urbana de Valencia desde Fernando el Católico a las germanías, Valencia.

Fernández Gómez, Margarita (1992), “El autor del Codex Escurialensis 28-II-12”, Academia, 74, pp. 123-162.

Fernández Gómez, Margarita (2000), Codex Escurialensis 28-II-12. Libro de dibujos o antigüedades, Murcia.

Ferragut, Concepción, Ferrer del Río, Estefania (2019), "Humanismo y mecenazgo en València a principios del s. XVI: los ejemplos de Juan Andrés Strany y Serafí de Centelles" en Arciniega García, Luis (coord.), Aproximaciones de contexto al castillo palacio de Alaquàs: sangre, tinta y piedra, Valencia, pp. 165-210.

Ferrer del Río, Estefania (2016a), "El primer enterramiento del I marqués del Cenete, Rodrigo Díaz de Vivar y Mendoza, en el convento de la Santísima Trinidad de Valencia", Chronica Nova, 42, pp. 245-258.

Ferrer del Río, Estefania (2016b), “De la bula de Julio II (1504) a las conclusiones de fray Pedro de Álava (1594): el largo proceso de validación del segundo matrimonio de Rodrigo de Mendoza, primer marqués del Cenete", Manuscrits: Revista d'història moderna, 34, pp. 13-34.

Ferrer del Río, Estefania (2017), "Successio ab intestato: a propósito de la muerte de Rodrigo de Mendoza, I marqués del Cenete”, Revista de historia moderna: Anales de la Universidad de Alicante, 35, pp. 467-496.

Ferrer del Río, Estefania (2018), "Rodrigo de Mendoza, I marqués del Cenete y I conde del Cid: paralelismos entre su biografía y su pretendida genealogía", Espacio, Tiempo y Forma. Serie III. Historia Medieval, 31, pp. 251-269.

Ferrer del Río, Estefania (2020), Rodrigo de Mendoza. Noble y coleccionista del Renacimiento, Madrid.

Ferrer del Río, Estefania, Ferrer Orts, Albert (2020), “El tercer viaje a Italia de Rodrigo de Mendoza, I marqués del Cenete", Chronica Nova, 46, pp. 297-319.

Gil Fernández, Luis (2003), Formas y tendencias del humanismo valenciano quinientista, Alcañiz-Madrid.

Gómez-Ferrer, Mercedes (2010), "Las almonedas de los libros del marqués de Zenete en 1529 y 1535 en Valencia”, Lemir: Revista de Literatura Española y del Renacimiento, 14, pp. 231-246. 
Gonzalo Sánchez-Molero, José Luis (2015), “Libros y bibliotecas portátiles: la biblioteca del embajador Lope Hurtado de Mendoza y de su hija Luisa de Rojas (1531-1542)" en Díez Borque, José María (dir.), Bibliotecas y librerías en la España de Carlos V, Barcelona, pp. 183-223.

Infantes, Víctor (1997), "Las ausencias en los inventarios de libros y de bibliotecas”, Bulletin hispanique, 99, pp. 281-292.

Kristeller, Paul Oscar (1962), “The European Diffusion of Italian Humanism”, Italica, 39, pp. 1-20.

López Serrano, Matilde (1972), La encuadernación española: breve historia, Madrid.

March, José María (1951), "El primer marqués del Cenete. Su vida suntuosa", Archivo Español de Arte, 24/93, pp. 47-66.

Marías, Fernando (2005), "El Codex Escurialensis: Problemas e incertidumbres de un libro de dibujos de antigüedades del último quattrocento", Reales Sitios: Revista del Patrimonio Nacional, 163, pp. 14-35.

Miguélez González, Elvira Julieta (2009), La encuadernación artística de la Biblioteca Histórica de la Universidad de Salamanca: estilos y técnicas, Salamanca.

Pedraza Gracia, Manuel José (1999), “Lector, lecturas, bibliotecas...: en el inventario como fuente para su investigación histórica”, Anales de documentación, 2, pp. 137-158.

Pedraza Gracia, Manuel José (2015), "El análisis de los inventarios para el estudio del lector y de la lectura: bibliotecas privadas y lectura en tiempos de Carlos I" en Díez Borque, José María (dir.), Bibliotecas y librerías en la España de Carlos $V$, Barcelona, pp. 11-32.

Pérez García, Pablo (2017), Las Germanías, en miniatura y al fresco, Valencia.

Petrarca, Francesco (1983), Epistole, Turín.

Petrucci, Armando (2011), Libros, escrituras y bibliotecas, Salamanca.

Quintanilla Raso, María Concepción (1980), "La biblioteca del Marqués de Priego (1518)", En la España Medieval, 1, pp. 347-384.

Redondo, Agustín (1967), "La bibliothèque de D. Francisco de Zúñiga Guzmán y Sotomayor, troisième duc de Béjar (1500?-1544)", Mélanges de la Casa de Velázquez, 3, pp. 147-196.

Rodrigo Lizondo, Mateu (2013-2014), "La llibreria del canonge Guillem Serra i el seu llegat a la Catedral de València (1489)", Butlletí de la Reial Acadèmia de Bones Lletres de Barcelona, 54, pp. 135-304.

Romero Medina, Raúl (2018), "De Italia a Sevilla: Lorenzo Vázquez de Segovia (c. 1450-1515). Arquitecto de los Mendoza” en Bermúdez López, Jesús et alii (eds.), El conde de Tendilla y su tiempo, Granada, pp. 727-745.

Ruiz García, Elisa, Carceller Cerviño, María del Pilar (2002), "La biblioteca del II Duque de Alburquerque (1467-1526)", Anuario de estudios medievales, 32/1, pp. 361-400.

Sánchez Cantón, Francisco Javier (1942), La biblioteca del marqués del Cenete iniciada por el cardenal Mendoza (1470-1523), Madrid. 
Sánchez Oliveira, Camino (2017), “Análisis del proceso de edición y producción de las cartas ejecutorias de hidalguía en pergamino: un modelo propio de confección y expedición documental” en Pedraza Gracia, Manuel José (dir.), Doce siglos de materialidad del libro. Estudios sobre manuscritos e impresos entre los siglos VIII y XIX, Zaragoza, pp. 385-400.

Scaglia, Gustina (2004), "El Codex Escurialensis llevado por el artista a la Calahorra en el otoño de 1509", Archivo Español de Arte, 77/308, pp. 373-383.

Solervicens Bo, Josep Vicent (2003), "La literatura humanística a la selecta biblioteca de Mencía de Mendoza, marquesa del Cenete, duquessa de Calàbria i deixebla de Joan Lluís Vives" en Pérez Durà, Jordi, Grau Codina, Ferran (coords.), La Universitat de València i l'Humanisme: Studia Humanitatis $i$ renovació cultural a Europa i al Nou Món, Valencia, pp. 313-324.

Soriano Robles, Lourdes (2010), "Sobre la tipologia material de la literatura artúrica peninsular: els textos" en Fradejas Rueda, José Manuel, Dietrick Smithbauer, Déborah, Martín Sanz, Demetrio, Díez Garretas, María Jesús (eds.), Actas del XIII Congreso Internacional de la Asociación Hispánica de Literatura Medieval: (Valladolid, 15-19 de de septiembre de 2009). In Memoriam Alan Deyermond, II, Valladolid, pp. 1697-1712.

Walther, Gerrit (2006), "Funktionen des Humanismus: Fragen und Thesen”, Funktionen des Humanismus. Studien zum Nutzen des Neuen in der humanistischen Kultur, Göttingen, pp. 9-17. 